\title{
Do Analysts' Preferences Affect Corporate Policies?
}

\author{
FRANÇOIS DEGEORGE, FRANÇOIS DERRIEN, AMBRUS KECSKÉS, and SÉBASTIEN \\ MICHENAUD*
}

\begin{abstract}
Equity research analysts tend to cover firms about which they have favorable views. We exploit this fact to infer analysts' preferences for corporate policies from their coverage decisions. We then use exogenous analyst disappearances to examine the effect of preferences on policies. After an analyst disappears, firms change their policies in the direction opposite to his preferences. Our results suggest that firms choose their corporate policies, in part, to be consistent with the preferences of their analysts.
\end{abstract}

November 26, 2012

JEL classification: G24, G31, G32, G34, G35

Keywords: Equity research analysts; Preferences; Real effects; Investment; Financing; Payouts; Leverage; Cash holdings

\footnotetext{
* Degeorge is at the University of Lugano - Swiss Finance Institute, Derrien is at HEC Paris, Kecskés is at the Virginia Polytechnic Institute and State University, and Sébastien Michenaud is at Rice University. We greatly appreciate the comments of Sumit Agarwal, Alan Crane, David De Angelis, Francesco Franzoni, Laurent Frésard, Patrick Gagliardini, Gustavo Grullon, Johan Hombert, Oğuzhan Karakaş, Roger Loh, Nadya Malenko, Roni Michaely, Jun Qian, Nagpurnanand Prabhala, Jérôme Taillard, James Weston, and seminar participants at Boston College, Hong Kong University of Science and Technology, Imperial College, Nanyang Technological University, National University of Singapore, Rice University, Singapore Management University, and the 2012 Summer Finance Conference at IDC Herzliya.
} 


\section{Introduction}

It is investors who are usually considered to be the primary audience of equity research analysts. The most visible outputs produced by analysts - investment recommendations and earnings estimates - are key inputs in investors' stock picking decisions, and an analyst's performance is typically evaluated based on whether investors benefit from his recommendations and estimates. Yet much of the research produced by analysts is actually directed not at investors but rather at the firms that they follow. Analysts often indicate explicitly that this is the case. For example, "[c]ompanies like Microsoft are "cash machines" that are "maturing," says Steve Milunovich, Merrill Lynch's top technology strategist, in a research piece ... that says it may be time for tech firms like Microsoft to consider dividends" (Buckman (2002)).

The financial press contains many similar examples. As one example, Dan Reingold writes about himself and his fellow analysts stating that, during the technology boom and bust, "we were ... pushing our vision of the industry out to the world with our research" (Reingold (2006) p.133). ${ }^{1}$ This paper asks whether analysts' preferences affect the corporate policies (investment, financing, payouts, etc.) of the firms that they cover.

We regard analyst preferences as having three properties. First, the preferences are specific to the analyst. Put another way, a preference is an analyst characteristic. Second, the preferences of an analyst are relative to other market participants and market conditions. Third, an analyst's preferences are constant across firms and across time. Conceptually, we think of analysts' preferences as systematic corporate policy biases relative to the consensus.

We offer some insights as to the possible determinants of analyst preferences. First, an analyst's expertise may determine his preferences. For example, an analyst may better understand

\footnotetext{
${ }^{1}$ This approach in industry goes back to at least the first half of the last century. For example, Graham and Dodd advise the following: "[The security analyst] must concern himself with all corporate policies ... On these matters ... security analysis may be competent to express critical judgments." (Graham and Dodd (1940) p. 32).
} 
the value implications of capex, so he may prefer firms with high capex because his opinions about such firms are most useful. Second, analyst preferences may be determined by personal tastes, unrelated to expertise and information (e.g., see Malmendier, Tate, and Yan (2011) for evidence on managers). An analyst who is conservative by nature, for example, may prefer firms that build assets rather than buy them and finance them internally rather than externally. The final determinant of an analyst's preferences may be his conflicts of interest: he prefers some corporate policies and not others because of his various incentives, especially the opposing incentives of stock picking for his investor clients and deal making for his firm clients.

Analysts express their preferences for corporate policies in their research reports, meetings with investors and managers, and even media interviews. We argue that firms choose corporate policies to be consistent with the preferences of their analysts for reasons that we term "analyst voice" and "analyst exit". It is well known that both more analyst coverage ${ }^{2}$ and more favorable analyst coverage ${ }^{3}$ cause higher stock prices. If firms want to avoid the loss of analyst coverage (exit) or unfavorable analyst coverage (voice), they should choose their corporate policies, on the margin, to be consistent with analyst preferences.

To identify analyst preferences, we exploit the fact that analysts tend to cover firms about which they have positive views and they tend not to cover firms about which they have negative views (e.g., McNichols and O'Brien (1997)). We assume that analysts' coverage decisions are based, in part, on their preferences for corporate policies. We estimate an analyst's preferences as the typical corporate policies pursued by the firms that he covers during his career. For example, we infer that analysts that tend to cover firms that make significant capital expenditures have a

\footnotetext{
${ }^{2}$ An increase in analyst coverage causes an increase in information asymmetry, which, in turn, decreases the cost of capital. See, e.g., Kelly and Ljungqvist (2012) for evidence from exogenous analyst disappearances.

${ }^{3}$ See, e.g., Womack (1996), Barber, Lehavy, McNichols, and Trueman (2001), Jegadeesh, Kim, Krische, and Lee (2004), and Loh and Stulz (2011).
} 
preference for capex. More precisely, for each of the policies that we consider, we use a panel of analyst-year-firm observations, and we regress the corporate policy on firm, year, and analyst fixed effects as well as control variables for the standard determinants of the policy. The analyst fixed effects capture the coverage decisions of analysts, and the coefficient estimates on them are our estimates of preferences for the policy. The preferences for corporate policies that we thus estimate for each analyst do not appear to be random compared to preferences that we simulate, and they appear to be consistent across a range of corporate policies. ${ }^{4}$

To identify the effect of analyst preferences on corporate policies, we examine the change in corporate policies after exogenous analyst disappearances. These analysts disappear (from the $\mathrm{I} / \mathrm{B} / \mathrm{E} / \mathrm{S}$ database) for such reasons as promotion, retirement, or even death, and in so doing they terminate coverage of all firms on their coverage list. When an analyst disappears, his preferences no longer affect the policies of the firms that he hitherto covered. Therefore, these firms should change their policies in the opposite direction to the preferences of the analyst that disappears.

Indeed, this is what we find. For example, when an analyst that prefers high capex disappears, the firms that he hitherto covered decrease their capex - in the direction opposite to the preferences of the analyst that disappears and in the same direction as the new mean preferences for capex of the other analysts. Our results are also monotonic and symmetric. That is, more positive (negative) preferences cause bigger decreases (increases) in policies (i.e., monotonicity), and the most extreme preferences, positive and negative, cause changes in policies that are similarly extreme in magnitude (i.e., symmetry). Finally, our results are stronger

\footnotetext{
${ }^{4}$ The method that we use to estimate analyst fixed effects is similar to that of Bertrand and Schoar (2003) and Cronqvist and Fahlenbrach (2009) who study the effect of managers and blockholders, respectively, on corporate policies. However, we take a different approach from these authors to estimate the effect of analyst preferences on corporate policies, one that is much closer to the approach of Fee, Hadlock, and Pierce (2012).
} 
for certain types of analysts and firms. Specifically, they are stronger when there is a greater difference in preferences between the analyst that disappears and the other analysts that cover the firm as well as when there are fewer analysts covering the firm. Our results are also stronger for firms with greater analyst attention, younger firms, and firms with better investment opportunities as well as higher valuations. Overall our results are consistent with our hypothesis that analysts' preferences affect the corporate policies of the firms that they cover.

We perform several robustness tests. First, we use a sample of analyst disappearances that has been used in the recent literature to study the effects of analysts in a variety of applications (e.g., Hong and Kacperczyk (2010) and Kelly and Ljungqvist (2012)). The analyst disappearances in question are those caused by broker closures and broker mergers. We confirm our results using this sample. Second, we examine whether our results are driven by a mechanical relationship between analyst preferences (estimated based on the corporate policies of the firms covered by analysts) and future changes in corporate policies. For example, mean reversion in corporate policies may drive our results. We provide numerous pieces of evidence against a mechanical relationship. Finally, we provide evidence that our analysts' preferences are distinct from the preferences of the brokers for which they work.

As far as we know, ours is the first paper to study the effect of analysts on corporate policies. Our study contributes to a stream of research on non-traditional determinants of corporate policies. For example, Bertrand and Schoar (2003) find that managerial style explains a significant part of the variation in corporate policies. Cronqvist and Fahlenbrach (2009) find that blockholders similarly matter. In another related study, Graham, Li, and Qiu (2012) find that managerial compensation is associated with the types of corporate policies that managers pursue. 
Our contribution is to provide evidence that the preferences of equity research analysts affect the corporate policies of the firms that they cover.

Our paper also contributes to the recent literature on the effects of financial markets on the real economy. Some papers study how stock prices affect equity issuance (Khan, Kogan, and Serafeim (2012)) and takeovers (Edmans, Goldstein, and Jiang (2012)). Others study how financial crises affect corporate investment (Duchin, Ozbas, and Sensoy (2010) and Almeida, Campello, Laranjeira, and Weisbenner (2011)). Still others study how short sales constraints affect a range of corporate policies (Grullon, Michenaud, and Weston (2011)). Our paper is perhaps closest to Derrien and Kecskés (2012), but whereas they study how analyst coverage affects corporate policies, we study how analyst preferences affect corporate policies.

The rest of this paper is organized as follows. Section 2 presents the methodology, sample, and data. Section 3 presents analyst preferences. Section 4 presents the effect of analyst preferences on corporate policies. Section 5 presents robustness tests. Section 6 concludes.

\section{Methodology, Sample, and Data}

To test our hypothesis that analyst preferences affect corporate policies, we proceed in two stages. First, we estimate analyst preferences. Second, we estimate the effect of these preferences on corporate policies. We now explain each of these stages in turn.

\subsection{Estimating Analyst Preferences}

We identify analysts' preferences for corporate policies using their coverage decisions. We assume that, on average, an analyst covers firms that pursue policies that reflect his preferences compared to the firms that he does not to cover. It may be that corporate policies consistent with analysts' preferences drive their coverage decisions. It may also be that firms pursue corporate policies that reflect the preferences of their analysts. The bottom line is that, on 
average, an analyst prefers the policies of the firms that he covers compared to the policies of the firms that he does not cover, whatever the direction of the causality.

It is implicit in our assumption above that analysts have some discretion in their coverage decisions. The decision to cover some firms, such as small, young, promising firms, is typically largely discretionary. Other coverage decisions are typically largely non-discretionary, such as the coverage of the leading firms in the analyst's industry, firms of particular interest to the analyst's investor clients, and firms that are past or prospective investment banking clients. We account for analyst discretion in our estimation of analyst preferences below. Moreover, although it is not explicit in our assumption above, we assume that analyst preferences are constant across firms and across time. Inasmuch as an analyst's expertise, tastes, and conflicts of interest - or other determinants of his preferences - change across firms and/or across time, we only capture the part of his preferences that is constant.

The sample that we use to estimate analyst preferences is a panel of all analysts, years, and firms, i.e., the unit of observation is a firm-year-analyst triple. The sample of firms comprises all publicly traded U.S. operating firms between 1984 and 2009 in CRSP, Compustat, and I/B/E/S excluding financials and utilities. To account for analyst discretion, we use a simple and sensible approach: we also exclude S\&P 500 firms in our estimation of analyst preferences. ${ }^{5}$ The sample of analysts comprises analysts that cover at least five firms per year for at least three years. This requirement ensures that our analyst preference measures are well defined in that they are not driven by a very small number of firms or a very small number of years. We assume that an analyst covers a firm during a year if that analyst has at least one earnings estimate for that firm that year.

\footnotetext{
${ }^{5}$ Our results are similar if we estimate preferences using both S\&P 500 and non-S\&P 500 firms.
} 
To estimate analyst preferences for a corporate policy, we estimate the following regression equation:

$$
\mathrm{CPV}_{\mathrm{i}, \mathrm{t}}=\alpha_{\mathrm{i}}+\beta_{\mathrm{t}}+\gamma_{\mathrm{j}}+\delta \cdot \mathrm{X}_{\mathrm{i}, \mathrm{t}-1}+\varepsilon_{\mathrm{i}, \mathrm{t}, \mathrm{j}}
$$

where $\mathrm{CPV}_{\mathrm{i}, \mathrm{t}}$ is a corporate policy variable for firm i at year $t, \alpha_{i}$ is the fixed effect of firm $\mathrm{i}, \beta_{\mathrm{t}}$ is the fixed effect for year $t, \gamma_{j}$ is the fixed effect of analyst $\mathrm{j}$, and $\mathrm{X}_{\mathrm{i}, \mathrm{t}-\mathrm{1}}$ are lagged control variables for firm $i$ at year $t-1$. The unit of observation $(\mathrm{j}, \mathrm{t}, \mathrm{i})$ is a analyst-year-firm triple. The analyst fixed effects are the coefficients on dummy variables that equal one for a given analyst, for a given year, and for a given firm if that analyst that year covers that firm, and they equal zero otherwise. These coefficients $\left(\gamma_{\mathrm{j}}\right)$ are the "analyst preferences" for that corporate policy. The control variables are size, market-to-book, cash flow-to-total assets, stock returns, and volatility, and they are defined in Appendix Table 1.

\subsection{Estimating the Effect of Analyst Preferences on Corporate Policies}

Our hypothesis is that analysts' preferences affect the corporate policies of the firms that they cover. The previous analysis only allows us to establish correlations between analyst coverage and corporate policies. A positive correlation may indicate that firms change their policies to be consistent with analyst preferences, but it may also simply indicate that coverage decisions are driven by current or anticipated corporate policies. To establish a causal link from analyst preferences to corporate policies, we use analyst disappearances. We assume that firms have some equilibrium corporate policies that are determined, in part, by the preferences of all analysts covering them as well as other factors. When an analyst disappears and thus the mean preferences of a firm's analysts change, the firm also changes its equilibrium corporate policies

in consequence. For example, a firm covered by an analyst that prefers high capex tends to increase its capex. If the analyst disappears, the firm should tend to decrease its capex. 
To establish causality, we must be sure that the analyst does not disappear for some reason related to the change in corporate policies of the firms that he covers. We focus on situations in which the analyst disappears completely, thus excluding selective terminations of coverage of specific firms. We do not expect analyst disappearances to be caused by anticipations of changes in the policies of the firm covered by these analysts.

We consider all analyst disappearances from the I/B/E/S database. These occur when an analyst leaves the profession due to promotion, retirement, or even death. We primarily use a sample of 15,158 analyst-year-firm observations between 1987 and 2009. There are 1,137 unique analysts in the sample and 4,182 unique firms. These firms are publicly traded U.S. operating firms excluding financials and utilities. The sample begins in 1987 because we require that analysts in our sample cover firms for at least three years. The sample ends in 2009 because we require one year with no analyst coverage to conclude that an analyst disappears. We deem that an analyst disappears in year $t$ if he covers some firms in year $t-1$ and he does not cover any firm in year $t+1$. In our robustness tests, we secondarily use a sample of analyst disappearances caused by broker closures or broker mergers. This approach is used in several recent papers that study the causal effects of analysts including their effects on corporate policies (e.g., see Hong and Kacperczyk (2010), Kelly and Ljungqvist (2012), and Derrien and Kecskés (2012)).

We examine how firms change their policies after an analyst disappears. If analyst preferences affect corporate policies, firms should change their policies in the direction opposite to the preferences of the analyst that disappears. For example, if firms covered by an analyst that prefers high capex increase their capex, then they should decrease their capex when the analyst disappears. To test this hypothesis, we run regressions of changes in corporate policies on the 
preferences of analysts that disappear as well as control variables. The regression equation that we estimate is:

$$
\left(\mathrm{CPV}_{\mathrm{i}, \mathrm{t}+1}-\mathrm{CPV}_{\mathrm{i}, \mathrm{t}-1}\right)=\alpha+\beta \cdot \mathrm{APV}_{\mathrm{j}}+\gamma \cdot \mathrm{X}_{\mathrm{i}, \mathrm{t}-1}+\varepsilon_{\mathrm{i}, \mathrm{t}, \mathrm{j}},
$$

where $\mathrm{CPV}_{\mathrm{i}, \mathrm{t}}$ is a corporate policy variable for firm $\mathrm{i}$ at year $\mathrm{t}, \mathrm{APV}_{\mathrm{j}}$ is the preference for analyst $\mathrm{j}$ that disappears at year $\mathrm{t}$, and $\mathrm{X}_{\mathrm{i}, \mathrm{t}}$ are control variables for firm $\mathrm{i}$ at year $\mathrm{t}$. The unit of observation $(\mathrm{i}, \mathrm{t}, \mathrm{j})$ is a firm-year-analyst triple. The sample comprises only analysts that disappear and only the firms that they cover during the year before they disappear. We expect $\beta$ to be negative if firms change their policies in the direction opposite to the preference of the analyst that disappears.

We examine a range of corporate policy variables that are studied in the corporate finance literature: variables for investment policies (both organic and inorganic); internal and external financing policies (debt and equity as well as changes in cash holdings); payout policies; and the classics, namely, leverage and cash holdings. The corporate policy variables that we use are: capital expenditures (CAPEX / TA), research and development expenditures ( $\mathrm{R} \& \mathrm{D} / \mathrm{TA}$ ), acquisitions expenditures (ACQN / TA), change in debt ( $\triangle$ DEBT / TA), equity issuance (EQUITY ISS / TA), dividends (DIV / TA), share repurchases (SHARE REP / TA), change in cash holdings ( $\triangle \mathrm{CASH} / \mathrm{TA}$ ), debt (DEBT / TA), and cash holdings (CASH / TA). We measure corporate policy variables in excess of mean industry-year corporate policy variables. This allows us to control for industry-specific and time-specific factors affecting corporate policies. Moreover, since year $\mathrm{t}$ is the year in which we deem that an analyst disappears, we measure changes in corporate policies from year $\mathrm{t}-1$ to year $\mathrm{t}+1$.

We recognize that there may be a mechanical relationship between analyst preferences and future changes in corporate policies. Specifically, our measures of analyst preferences may 
be affected by abnormally high or low levels of these past corporate policies and thus they may be mechanically related to future changes in these corporate policies. For example, some corporate policies like capex may be mean reverting. To account for such a mechanical relationship, we control for past levels of corporate policies. In our main results, we use one past level of corporate policies (at year t-2). Using several past levels of corporate policies captures a richer mechanical relationship between changes in corporate policies for a firm across time, but it also decreases the sample size significantly. Since our results are similar for one lag and many lags, we only tabulate results for one lag. We also perform several robustness tests below.

The control variables that we use are: size, market-to-book, cash flow-to-total assets, stock returns, and volatility. All variables are defined in Appendix Table 1. Stock trading data are from CRSP, accounting data are from Compustat, and analyst data are from I/B/E/S. We winsorize all continuous variables at the $1^{\text {st }}$ and $99^{\text {th }}$ percentiles.

\section{Analyst Preferences}

[Insert Table 1 about here]

We examine analyst preferences estimated using Equation (1) starting with their distribution. These preferences correspond to our sample of 1,811 analysts between 1984 and 2009. Table 1 presents various percentiles of the distribution of analyst preferences. The analyst preferences that we estimate are generally quite symmetric. They tend to be either positive or negative, and this is an artifact of the specification that we use to estimate them. However, this is not a problem because in our analysis we simply need to be able to compare the preferences of one analyst relative to another. We do not need to know whether an analyst absolutely likes or dislikes a particular corporate policy. 
Next, we examine the extent to which the analyst preferences that we estimate are random. We compare the true analyst preferences that we estimate to analyst preferences that we simulate. We simulate analyst preferences as follows. For every analyst, for every year, and for every industry covered by the analyst, we randomly assign firms to the analyst in such a way that the number of randomly assigned firms in the industry equals the number of true firms covered by the analyst in the industry. Firms covered by more analysts have a proportionately higher probability of being selected. After each random assignment, we compute analyst preferences. We generate simulated analyst preferences through 1,000 iterations of this procedure.

[Insert Figure 1 about here]

We compare the distributions of true and simulated analyst preferences for each corporate policy through both histograms and Kolmogorov-Smirnov tests. Figure 1 presents the results for the histograms, and Table 1 presents the results for the Kolmogorov-Smirnov tests. The true distribution is visibly different from the simulated distributions for all corporate policies. Similarly, the Kolmogorov-Smirnov test rejects the null hypothesis of equality of the distributions with high significance for all corporate policies. Overall, the results suggest that the analyst preferences that we estimate are not random but rather capture some analyst characteristic.

\section{[Insert Table 2 about here]}

We also compute correlations between analyst preferences to examine whether they are consistent across corporate policies. Table 2 presents the results. In terms of the big picture, only capital expenditures and $\mathrm{R} \& \mathrm{D}$ expenditures are correlated (weakly positively so) among the three investment preferences. Debt and equity issuance are uncorrelated. Financial slack (the change in cash holdings) is weakly positively correlated with the change in debt and strongly 
positively correlated with equity issuance. It is also and negatively correlated with dividends. This suggests that analysts that prefer increases in financial slack also prefer more debt issuance and equity issuance and less dividends. Finally, both payout preferences are strongly correlated with each other. Put another way, analysts that prefer dividends also prefer share repurchases.

In more detail, investment preferences are highly positively correlated with change in debt preferences for both capital expenditures and acquisitions expenditures but not for research and development expenditures. All investment preferences are also positively but only weakly correlated with equity issuance preferences. At the same time, all investment preferences are negatively and weakly correlated with change in cash holdings preferences. This is consistent with analysts strongly preferring investment financed with debt (except for research and development expenditures) and weakly preferring it to be financed with equity. They also weakly prefer decreases in financial slack to finance investment. Investment preferences also tend to be weakly negatively correlated with dividends preferences but not for research and development expenditures preferences, which are, somewhat surprisingly, positively correlated with dividends preferences. Share repurchases preferences are only correlated with capital expenditures preferences, and, in that case, negatively. In other words, analysts that prefer investment weakly prefer less payouts.

Finally, we examine leverage and cash holdings - two corporate policies at the very heart of corporate finance. Analysts that prefer high leverage also prefer low cash holdings. Reassuringly, preferences for higher leverage are positively correlated with preferences for the change in debt and negatively with preferences for equity issuance and dividends but uncorrelated with preferences for share repurchases. Analysts' preferences between investment and leverage are less consistent. Reassuringly again, analysts that prefer higher cash holdings 
also prefer greater changes to cash holdings. Taken as a whole, the results suggest that our analyst preferences are fairly consistent across corporate policies.

In our final analysis of analyst preferences, we compare our full sample to a sample of analyst disappearances caused by broker closures and broker mergers that is used in other papers (already mentioned) that study the effects of exogenous analyst disappearances. We do so to examine the extent to which analyst preferences in our full sample are "normal". If analyst disappearances in both samples are similar, we can rule out the possibility that the analysts that disappear in our full sample have "extreme" preferences (based on the corporate policies of the typical firms that they cover during their career) and they disappear because they have extreme preferences.

We construct this sample as those analyst disappearances in our full sample that are also in the sample of Derrien and Kecskés (2012). This sample is about 5\% of the sample size of our full sample. For each corporate policy, we examine whether analyst preferences are similar for both samples by testing the equality of the means, medians, and distributions (using the Kolmogorov-Smirnov test). Our results (not tabulated) indicate that none of the means or medians is significantly different. Eight of the ten distributions are not significantly different either at the $5 \%$ level, and none of them are significant at the $10 \%$ level. Overall, our analyst preferences appear to be "normal".

\section{Analyst Preferences and Corporate Policies}

\subsection{Descriptive Statistics}

[Insert Figure 2 about here]

We begin by providing descriptive statistics for our sample. First, we count the number of analysts that disappear and firms that lose an analyst each year in our sample. Figure 2 presents 
the results. There is some clustering in calendar time both in the analysts that disappear and the firms that lose an analyst. There tends to be a below average number of analysts and firms in the early 1990s and an above average number in the early 2000s. However, such temporal clustering does not affect our results because we measure changes in corporate policies for a given firm in a given year in excess of the mean change in corporate policies of the firms in the same industry and the same year.

\section{[Insert Table 3 about here]}

Second, we examine the distribution of firm characteristics and changes in corporate policies. Table 3 presents the results. Panel A shows that our sample firms are big both in terms of analyst coverage and market capitalization: the mean and median firm has analyst coverage of 15.4 analysts and 7.0 analysts, respectively, and a market capitalization of $\$ 5.1$ billion and $\$ 0.9$ billion, respectively. Panel B shows that for the most part, both in terms of the mean and the median, our changes in corporate policies are close to zero. This is by construction: we measure changes in corporate policies in excess of changes in mean industry-year corporate policies.

\subsection{Univariate Analysis of the Effect of Corporate Policies on Analyst Preferences}

We now examine how analyst preferences affect corporate policies in a univariate setting.

Our motivation for doing so is twofold. First, we wish to examine if and how quickly corporate policies change when an analyst disappears. Second, we wish to examine whether the future changes in corporate policies caused by the preferences of the analyst that disappears after the analyst disappears and not before. If this were the case, it would be consistent with a causal effect of analyst preferences on corporate policies.

To this end, we compute mean corporate policies in event time for firms conditional upon the preferences of the analyst that disappears. For each corporate policy, we classify analysts that 
disappear with preferences above the median as analysts with positive preferences and we classify analysts with preferences below the median as analysts with negative preferences. For firms in each of the two analyst preferences groups, we compute mean corporate policies each year from three years before the analyst disappears to three years thereafter.

\section{[Insert Figure 3 about here]}

Figure 3 presents the results. Between year -3 and year -1 , corporate policies are roughly parallel for both positive and negative preferences groups. However, they change significantly between year -1 and year +1 . Consistent with our hypothesis, policies generally increase during that period for the negative preferences group and they generally decrease for the positive preferences group. In other words, the corporate policies of firms change in the direction opposite to the preference of the analyst that disappears. Moreover, between year +1 and year +3 , corporate policies are once again roughly parallel for both the positive and negative preferences group.

In summary, Figure 3 shows that corporate policies change quickly (as a function of analyst preferences) when an analyst disappears. Moreover, corporate policies change after an analyst disappears and not before, which is consistent with analyst preferences having a causal effect on corporate policies. Finally, since changes in corporate policies are concentrated between year -1 and year +1 , we focus the rest of our analysis on this period.

\subsection{Multivariate Analysis of the Effect of Analyst Preferences on Corporate Policies}

Next, we examine how analyst preferences affect corporate policies in a multivariate setting. To this end, we estimate Equation (2). We regress future changes in corporate policy variables on analyst preference variables as well as control variables.

[Insert Table 4 about here] 
Table 4 presents the results. ${ }^{6}$ They show that changes in corporate policies are negatively related to analyst preferences for all corporate policies. This is consistent with our hypothesis that analyst preferences affect corporate policies, so when an analyst disappears, the firms that he covers change their policies away from his preferences and toward the preferences of the other analysts that cover the firm. The results are both economically and statistically significant. A one-standard deviation change in analyst preferences is associated with a decrease in capital expenditures of roughly $0.3 \%$ of total assets. The economic magnitudes for other corporate policies are generally similar: dividends have the smallest economic magnitudes (roughly $0.07 \%$ ) and the equity issuance has the biggest (roughly $-1.3 \%$ ).

To put our results in perspective, we compare them with the results of Bertrand and Schoar (2003) and Cronqvist and Fahlenbrach (2009). These authors examine the effects on corporate policies of managers and blockholders, respectively, as captured by "fixed effects" for these economic agents. By way of example, both Bertrand and Schoar (2003) and Cronqvist and Fahlenbrach (2009) estimate the effect of an increase from the $25^{\text {th }}$ percentile to the $75^{\text {th }}$ percentile of the distribution their fixed effects. For manager fixed effects, the effect on capital expenditures is 20 percentage points compared to mean capital expenditures of $30 \%$ of property, plant, and equipment; for blockholder fixed effects, the corresponding figures are an increase of 17 percentage points compared to a mean of $28 \%$. For leverage, the corresponding figures are 16 percentage points compared to $34 \%$ for manager fixed effects and 16 percentage points compared to a mean of $37 \%$ for blockholder fixed effects.

\footnotetext{
${ }^{6}$ We examine several alternative specifications. First, we control for the mean of the preferences of other analysts that cover the firm. Second, we include year fixed effects or firm fixed effects. Third, we use several past levels of corporate policies rather than just one. Finally, we split our sample period into the following roughly five-year subperiods: 1987-1990, 1991-1995, 1996-2000, 2001-2005, and 2006-2009. In all of these alternative specifications, the results are similar to the results in Table 4.
} 
Our results are significantly smaller in economic magnitude. However, since we use shocks to the influence of analysts, our results capture only the pure effect of this influence. By contrast, Bertrand and Schoar (2003) and Cronqvist and Fahlenbrach (2009) may also capture various facets of the endogeneity between managers and blockholders, respectively, and corporate policies. Alternatively, a single analyst may simply be less economically important in influencing firms than a manager or a blockholder.

In an alternative specification, we account for both the preferences of the analyst that disappears as well as the preferences of the other analysts that cover the firm. We do so, first, because the effect of the analyst that disappears should be bigger if his preferences are further away from the mean preferences of the other analysts. Second, the effect of a single analyst should also be bigger if there are fewer analysts covering the firm and smaller if there are many analysts.

We take into account both the distance between the analyst that disappears and other analysts that cover the firm as well as the number of analysts that cover the firm. To this end, we use the change in the mean of the preferences of all analysts covering the firm between year t-1 and year $\mathrm{t}+1$. "All analysts" at year $\mathrm{t}-1$ include the analyst that disappears and they exclude him at $\mathrm{t}+1$. In computing this change, we hold the group of "other analysts" fixed: except for the analyst that disappears, we assume that all analysts that cover the firm in year t-1 still cover it in year $t+1$. We do this to avoid the effect on mean preferences of endogenous decisions to initiate or terminate coverage of the firm between year $\mathrm{t}-1$ and year $\mathrm{t}+1$. Contrary to our previous tests, we expect that, after an analyst disappears, firms change their corporate policies in the same direction as the change in the mean of the preferences of all analysts. For example, if the analyst 
that disappears likes capex more than the average other analyst, then the average preference for capex decreases after he disappears, which, in turn, should cause the firm to decrease its capex.

[Insert Table 5 about here]

Table 5 presents the results. Reassuringly, changes in corporate policies are positively related to changes in the preferences of all analysts. The results are consistent with our hypothesis that the typical preferences of a firm's analysts affect its choice of corporate policies. This is the case even accounting for the distance between the preferences of the analyst that disappears and the preferences of other analysts that cover the firm as well as the number of analysts that cover the firm.

\subsection{Monotonicity and Symmetry of Results}

A possible concern with the previous results is that analyst disappearances and changes in corporate policies may coincide with changes in economic conditions. These changes in economic conditions, then, are what may cause both analysts to disappear and firms to change their corporate policies. In this case, there should be big decreases in corporate policies if the analyst that disappears has strong positive preferences and no changes in corporate policies if the analyst has strong negative preferences. Put another way, our results should not be symmetric.

Figure 3 suggests that changes in corporate policies after analyst disappearances are fairly symmetric. However, we also examine this symmetry in the multivariate setting of Table 4 . Instead of using analyst preferences themselves, we use dummy variables for quintiles of analyst preferences. The dummy variable that we omit is the dummy variable for the middle (third) quintile of analyst preferences.

[Insert Table 6 about here] 
Table 6 presents the results. Analyst preferences affect corporate policies monotonically. Specifically, the most positive preferences (in quintile 5) have a strong negative effect on policies (except for dividends). The less positive preferences (in quintile 4) have a weak but generally negative effect on policies. The less negative preferences (in quintile 2) have a weak but generally positive effect on policies. Finally, the most negative preferences (in quintile 1) have a strong positive effect on policies (except for the change in debt).

Moreover, analyst preferences affect corporate policies symmetrically. The less positive preferences (in quintile 4) and the less negative preferences (in quintile 2) generally have an economically and statistically weak effect on policies, so they are difficult to interpret. However, the most positive preferences (in quintile 5) and the most negative preferences (in quintile 1) have an economically and statistically strong effect on policies, and their effects are generally of similar magnitudes but of opposite directions. Overall, our results are incompatible with the concern that analyst disappearances and changes in corporate policies coincide with changes in economic conditions.

\subsection{Results Conditional Upon Additional Analyst Characteristics and Firm Characteristics}

Finally, we examine our results conditional upon various additional analyst characteristics and firm characteristics. We have already found that our results are stronger if there is a bigger distance between the preferences of the analyst that disappears and the preferences of the other analysts that cover the firm (Table 5). Similarly, our results are stronger if there are fewer analysts covering the firm.

We now examine how our results depend, first, on analyst attention. The change in corporate policies should be bigger for firms for which the analyst that disappears pays more attention. We capture analyst attention using the number of firms covered by the analyst that 
disappears. Second, the change in corporate policies should be bigger for younger firms. Younger firms tend to depend on external financing, be neglected by financial market participants, and have more information asymmetry. Analysts can alleviate these problems. We capture firm age as using the number of years the firm has been publicly traded. Finally, the change in corporate policies should be bigger for firms with better investment opportunities and higher valuations. Analysts can be helpful in raising financing as well as supporting a firm's stock price. We capture both investment opportunities and valuation using market-to-book. We redo our results in Table 4 conditional upon these various analyst and firm characteristics.

\section{[Insert Table 7 about here]}

Table 7 presents the results. Panel A shows that the interaction of analyst preferences and the number of firms covered by the analyst is typically positive (for eight out of ten corporate policies) and significant. Thus our results are stronger for firms with more analyst attention. Similarly, Panel B shows that the interaction of analyst preferences and firm age is positive (for all ten corporate policies) and typically significant. In other words, our results are stronger for younger firms. Finally, Panel $\mathrm{C}$ shows that the interaction of analyst preferences and market-tobook is typically negative (for eight out of ten corporate policies) and significant (for five of these). Put another way, our results are stronger for firms with better investment opportunities and higher valuations.

We also examine whether our results are stronger for star analysts (based on Institutional Investor magazine). Although we do not find that this is the case, there are several possible reasons for this. First, more analysts with influence such as star analysts may cover firms that are less subject to influence. Hence the effect of star analysts on the firms that they cover should be the same as the effect on non-star analysts on their firms. Second, the star status of an analyst, as 
it is conventionally measured, is determined by his popularity with institutional investors, which vote based on analysts' investment advice for money managers. Inasmuch as star status is not related to analysts' corporate policy advice for corporate managers, star analysts should have the same effect on corporate policies as non-star analysts. Finally, the analyst preferences that we examine may be determined primarily by irrational factors such as tastes rather than rational factors such as expertise. Star analysts may know this about their preferences and weight them more lightly to the firms that they cover. Therefore, even if firms weight the preferences of stars more heavily, the net effect may be that star analysts have the same effect as non-star analysts. In summary, there are several possible reasons to think that our results should not be stronger for star analysts.

\section{Robustness Tests}

We perform several robustness tests of our results. In all of our tests, we redo Table 4 with some modifications. In our first robustness test, we use a sample of analyst disappearances caused by broker closures and broker mergers instead of our full sample. We construct this sample as those analyst disappearances in our full sample that are also in the sample of Derrien and Kecskés (2012). This sample is about 5\% of the sample size of our full sample, so it produces considerably less precise estimates. However, it has the advantage of closely following the literature on the effects of exogenous analyst disappearances. This sample comprises 747 analyst-year-firm observations between 1994 and 2008 corresponding to 60 unique analysts that disappear and 606 unique firms.

[Insert Table 8 about here]

Table 8 Panel A presents the results. These results are consistent with those of Table 4 (with the exception of research and development expenditures). They have somewhat less 
statistical significance, but this is primarily because of the smaller sample size. They are generally comparable in terms of economic significance.

In our next two robustness tests, we examine whether there is a mechanical relationship between analyst preferences and changes in corporate policies. First, we perform a placebo test before the analyst disappears. Specifically, we move back by two years all variables except analyst preferences. If there is a mechanical relationship between analyst preferences and changes in corporate policies, then our results should also obtain two years before the analyst actually disappears. Table 8 Panel B presents the results. The results are statistically significant for five corporate policies, but they are inconsistent with a mechanical relationship between analyst preferences and changes in corporate policies (the coefficient estimates that are statistically significant are positive, not negative).

Second, we examine whether our results are stronger when the mechanical relationship between analyst preferences and changes in corporate policies should be stronger. Specifically, we condition upon the length of the estimation period for analyst preferences. What may be happening, for example, is that analyst preferences for capex may be capturing an increase in capex in the past, which, if capex is mean reverting, will be associated with a decrease in capex in the future. The association between past "analyst preferences for capex" and future decreases in capex should be stronger if "analyst preferences" are measured during a few years in the past rather than many years in the past. We redo Table 4 also adding a short estimation period dummy variable and the interaction of analyst preferences with the short estimation period dummy variable. The short estimation period dummy variable equals one if the analyst preference estimation period is below the median and it equals zero otherwise. 
Table 8 Panel $\mathrm{C}$ presents the results. The interaction term is statistically significant for only two corporate policies, and only for one of these two (cash holdings) are the results consistent with a mechanical relationship. Even in this one case, the effect of analyst preferences on corporate policies remains significant: the coefficient estimate is -18.8 in Table 8 Panel $\mathrm{C}$ compared to -35.4 in Table 4 , or $47 \%$ smaller. Once again, taken as a whole, the results are inconsistent with a mechanical relationship between analyst preferences and changes in corporate policies.

In our final robustness test, we examine the possibility that our analyst preferences in fact capture the preferences of the broker for which the analyst works. Brokers' preferences may be driven, for example, by the objectives of their investor clients and firm clients. This possibility is consistent with the results of Cronqvist and Fahlenbrach (2009), who find a correlation between specific institutional investors and specific corporate policies. We consider this possible explanation by adding broker fixed effects to our analysis. Table 8 Panel D presents the results. For analyst preferences, the results are similar, both economically and statistically, to the results in Table 4. For broker preferences, the results are generally not significant economically or statistically. (When they are statistically significant, they have the wrong sign.)

\section{Conclusion}

Equity research analysts produce information that affects not only their investor clients' trading decisions but also their firm clients' corporate policy decisions. While this insight is well known in the financial services industry, it is essentially unknown in the academic literature. In this paper, we formally study how analysts' preferences affect the investment, financing, and payout policies of the firms that they cover. 
We identify these analysts' preferences for corporate policies using their coverage decisions. After estimating analyst preferences, we find that they are both non-random and consistent across a range of corporate policies. We identify the effect of analyst preferences on corporate policies by examining the change in corporate policies after exogenous analyst disappearances. We find that firms change their policies in the direction opposite to the preferences of the analyst that disappears. We conclude that analyst preferences affect corporate policies. In doing so, we contribute to the literature on the non-traditional determinants of corporate policies as well as the literature on the effects of financial markets on the real economy. 


\section{References}

Almeida, Heitor, Murillo Campello, Bruno Laranjeira, and Scott Weisbenner, 2011, Corporate debt maturity and the real effects of the 2007 credit crisis, Critical Finance Review 1, 358.

Barber, Brad, Reuven Lehavy, Maureen McNichols, and Brett Trueman, 2001, Can investors profit from the prophets? Security analyst recommendations and stock returns, Journal of Finance 56, 531-564.

Bertrand, Marianne, and Antoinette Schoar, 2003, Managing with style: The effect of managers on firm policies, Quarterly Journal of Economics 118, 1169-1208.

Buckman, Rebecca, 2002, Heard on the street: A cash-rich Microsoft faces shareholder call for dividend, Wall Street Journal, January 2.

Cronqvist, Henrik, and Rüdiger Falhenbrach, 2009, Large shareholders and corporate policies, Review of Financial Studies 22, 3941-3976.

Derrien, François, and Ambrus Kecskés, 2012, The real effects of financial shocks: Evidence from exogenous changes in analyst coverage, forthcoming Journal of Finance.

Duchin, Ran, Oguzhan Ozbas, and Berk A. Sensoy, 2010, Costly external finance, corporate investment, and the subprime mortgage credit crisis, Journal of Financial Economics 97, 418-435.

Edmans, Alex, Itay Goldstein, and Wei Jiang, 2012, The real effects of financial markets: The impact of prices on takeovers, Journal of Finance 67, 933-971.

Fee, C. Edward, and Charles J. Hadlock, and Joshua R. Pierce, 2012, Managers with and without Style: Evidence from Exogenous Variation, forthcoming Review of Financial Studies. 
Graham, Benjamin, and David L. Dodd, 1940. Security Analysis: Principles and Technique (McGraw-Hill, New York, NY).

Graham, John R., Si Li, and Jiaping Qiu, 2012, Managerial attributes and executive compensation, Review of Financial Studies 25, 144-186.

Grullon, Gustavo, Sébastien Michenaud, and James P. Weston, 2011, The real effects of stock market prices, working paper.

Hong, Harrison, and Jeffrey D. Kubik, 2003, Analyzing the analysts: Career concerns and biased earnings forecasts, Journal of Finance 58, 313-351.

Hong, Harrison, and Marcin Kacperczyk, 2010, Competition and bias, Quarterly Journal of Economics 125, 1683-1725.

Jegadeesh, Narasimhan, Joonghyuk Kim, Susan D. Krische, and Charles Lee, 2004, Analyzing the analysts: When do recommendations add value?, Journal of Finance 59, 1083-1124.

Kelly, Bryan, and Alexander Ljungqvist, 2012, Testing asymmetric-information asset pricing models, Review of Financial Studies 25, 1366-1413.

Khan, Mozaffar, Leonid Kogan, and George Serafeim, 2012, Mutual fund trading pressure: Firm-level stock price impact and timing of SEOs, Journal of Finance 67, 1371-1395.

Loh, Roger K., and René M. Stulz, 2011, When are analyst recommendation changes influential?, Review of Financial Studies 24, 593-627.

Malmendier, Ulrike, Geoffrey Tate, and Jon Yan, 2011, Overconfidence and early-life experiences: The effect of managerial traits on corporate financial policies, Journal of Finance 66, 1687-1733.

McNichols, Maureen F., and Patricia C. O'Brien, 1997, Self-selection and analyst coverage, Journal of Accounting Research 35, 167-199. 
Reingold, Dan, 2006. Confessions of a Wall Street Analyst: A True Story of Inside Information and Corruption in the Stock Market (Collins, New York, NY).

Womack, Kent, 1996, Do brokerage analysts' recommendations have investment value?, Journal of Finance 51, 137-167. 


\section{Table 1}

\section{Distribution of Analyst Preferences}

This table presents the distribution of analyst preferences. The sample comprises 1,811 analysts between 1984 and 2009. All variables are defined in Appendix Table 1. The p-values are the p-values of the Kolmogorov-Smirnov test of the equality of the distributions of the true and simulated analyst preferences for corporate policies.

\begin{tabular}{|c|c|c|c|c|c|c|c|c|c|c|}
\hline & $\begin{array}{c}\text { CAPEX / } \\
\text { TA } \\
\end{array}$ & $\begin{array}{c}\mathrm{R} \& \mathrm{D} / \\
\mathrm{TA}\end{array}$ & $\begin{array}{c}\mathrm{ACQN} / \\
\mathrm{TA} \\
\end{array}$ & $\begin{array}{c}\Delta \mathrm{DEBT} / \\
\mathrm{TA} \\
\end{array}$ & $\begin{array}{l}\text { EQUITY } \\
\text { ISS / TA }\end{array}$ & DIV / TA & $\begin{array}{r}\text { SHARE } \\
\text { REP / TA } \\
\end{array}$ & $\begin{array}{c}\Delta \mathrm{CASH} / \\
\mathrm{TA} \\
\end{array}$ & $\begin{array}{c}\text { DEBT / } \\
\text { TA }\end{array}$ & $\begin{array}{c}\mathrm{CASH} / \\
\mathrm{TA} \\
\end{array}$ \\
\hline Mean & $1.50 \%$ & $0.73 \%$ & $-2.63 \%$ & $1.59 \%$ & $0.85 \%$ & $-0.06 \%$ & $-0.49 \%$ & $-0.71 \%$ & $1.46 \%$ & $5.90 \%$ \\
\hline Standard deviation & $1.18 \%$ & $0.94 \%$ & $0.98 \%$ & $0.78 \%$ & $1.72 \%$ & $0.17 \%$ & $0.75 \%$ & $1.43 \%$ & $2.90 \%$ & $2.53 \%$ \\
\hline $5^{\text {th }}$ percentile & $-0.07 \%$ & $-0.46 \%$ & $-4.18 \%$ & $0.34 \%$ & $-1.68 \%$ & $-0.32 \%$ & $-1.62 \%$ & $-2.95 \%$ & $-3.34 \%$ & $2.01 \%$ \\
\hline $10^{\text {th }}$ percentile & $0.36 \%$ & $-0.16 \%$ & $-3.75 \%$ & $0.73 \%$ & $-0.99 \%$ & $-0.25 \%$ & $-1.36 \%$ & $-2.29 \%$ & $-2.10 \%$ & $3.06 \%$ \\
\hline $25^{\text {th }}$ percentile & $0.94 \%$ & $0.28 \%$ & $-3.19 \%$ & $1.17 \%$ & $-0.05 \%$ & $-0.15 \%$ & $-0.94 \%$ & $-1.48 \%$ & $-0.33 \%$ & $4.53 \%$ \\
\hline $50^{\text {th }}$ percentile & $1.44 \%$ & $0.68 \%$ & $-2.65 \%$ & $1.58 \%$ & $0.80 \%$ & $-0.06 \%$ & $-0.50 \%$ & $-0.73 \%$ & $1.50 \%$ & $5.72 \%$ \\
\hline $75^{\text {th }}$ percentile & $1.93 \%$ & $1.04 \%$ & $-2.07 \%$ & $1.99 \%$ & $1.71 \%$ & $0.02 \%$ & $-0.11 \%$ & $0.03 \%$ & $3.12 \%$ & $7.18 \%$ \\
\hline $90^{\text {th }}$ percentile & $2.59 \%$ & $1.52 \%$ & $-1.47 \%$ & $2.50 \%$ & $2.74 \%$ & $0.13 \%$ & $0.34 \%$ & $0.94 \%$ & $4.86 \%$ & $8.99 \%$ \\
\hline $95^{\text {th }}$ percentile & $3.34 \%$ & $2.12 \%$ & $-1.04 \%$ & $2.87 \%$ & $3.61 \%$ & $0.22 \%$ & $0.74 \%$ & $1.72 \%$ & $6.09 \%$ & $10.09 \%$ \\
\hline p-value: true vs. simulated & 0.000 & 0.000 & 0.000 & 0.000 & 0.000 & 0.000 & 0.000 & 0.000 & 0.000 & 0.000 \\
\hline
\end{tabular}


Table 2

Correlations Between Analyst Preferences

This table presents correlations between analyst preferences. The sample comprises 1,811 analysts between 1984 and 2009. All variables are defined in Appendix Table $1 .{ }^{* *}, * *$, and $*$ indicate statistical significance at the $1 \%, 5 \%$, and $10 \%$ levels, respectively.

\begin{tabular}{|c|c|c|c|c|c|c|c|c|c|c|}
\hline & $\begin{array}{c}\text { CAPEX / } \\
\text { TA } \\
\end{array}$ & $\begin{array}{c}\mathrm{R} \& \mathrm{D} / \\
\mathrm{TA}\end{array}$ & $\begin{array}{c}\mathrm{ACQN} / \\
\mathrm{TA}\end{array}$ & $\begin{array}{c}\Delta \text { DEBT / } \\
\text { TA }\end{array}$ & $\begin{array}{l}\text { EQUITY } \\
\text { ISS / TA }\end{array}$ & DIV / TA & $\begin{array}{c}\text { SHARE } \\
\text { REP / TA }\end{array}$ & $\begin{array}{c}\Delta \mathrm{CASH} / \\
\mathrm{TA} \\
\end{array}$ & $\begin{array}{c}\text { DEBT / } \\
\text { TA }\end{array}$ & $\begin{array}{c}\text { CASH / } \\
\text { TA }\end{array}$ \\
\hline CAPEX / TA & - & & & & & & & & & \\
\hline $\mathrm{R} \& \mathrm{D} / \mathrm{TA}$ & $0.08 * * *$ & - & & & & & & & & \\
\hline ACQN / TA & -0.04 & -0.02 & - & & & & & & & \\
\hline$\Delta \mathrm{DEBT} / \mathrm{TA}$ & $0.30 * * *$ & 0.03 & $0.25 * * *$ & - & & & & & & \\
\hline EQUITY ISS / TA & $0.11 * * *$ & $0.07 * * *$ & 0.02 & -0.03 & - & & & & & \\
\hline DIV / TA & $-0.14 * * *$ & $0.06 * *$ & $-0.12 * * *$ & $-0.07 * * *$ & $0.06 * *$ & - & & & & \\
\hline SHARE REP / TA & $-0.26 * * *$ & $-0.06 * *$ & 0.00 & -0.02 & 0.04 & $0.29 * * *$ & - & & & \\
\hline$\Delta \mathrm{CASH} / \mathrm{TA}$ & $-0.05 * *$ & $-0.17 * * *$ & -0.03 & $0.09 * * *$ & $0.29 * * *$ & $-0.05 * *$ & -0.02 & - & & \\
\hline DEBT / TA & $-0.23 * * *$ & $-0.16^{* * *}$ & $0.12 * * *$ & $0.15 * * *$ & $-0.33 * * *$ & $-0.14 * * *$ & 0.00 & 0.03 & - & \\
\hline CASH / TA & $-0.09 * * *$ & $0.05^{*}$ & $-0.09 * * *$ & $-0.12 * * *$ & $0.29 * * *$ & $0.12 * * *$ & 0.03 & 0.03 & $-0.33 * * *$ & - \\
\hline
\end{tabular}


Table 3

\section{Descriptive Statistics}

This table presents various descriptive statistics for firm characteristics and changes in corporate policies. The sample comprises 15,158 analyst-year-firm observations corresponding to 1,137 unique analysts and 4,182 unique firms between 1987 and 2009. The analysts in the sample disappear and terminate coverage of all firms on their coverage list. The firms in the sample are publicly traded U.S. operating firms excluding financials and utilities. All variables are defined in Appendix Table 1. An analyst is deemed to disappear in year $t$ if he covers some firms in year $t-1$ and he does not cover any firm in year $t+1$. In Panel A, firm characteristics are measured at the year before the analyst disappears ( $t-1)$. In Panel B, changes in corporate policy variables are measured in excess of changes in mean industry-year corporate policy variables and are expressed as a percent of total assets. They are measured from the year before the analyst disappears ( $\mathrm{t}-1)$ to the year thereafter $(\mathrm{t}+1)$.

\begin{tabular}{|c|c|c|c|c|c|c|c|}
\hline \multicolumn{8}{|c|}{ Panel A: Firm Characteristics } \\
\hline & $\begin{array}{l}\text { Analyst } \\
\text { coverage }\end{array}$ & $\begin{array}{l}\text { Market cap } \\
(\$ M)\end{array}$ & $\begin{array}{l}\text { Total assets } \\
(\$ M)\end{array}$ & Market-to-book & $\begin{array}{l}\text { Cash flow-to- } \\
\text { total assets }\end{array}$ & Stock returns & Volatility \\
\hline Mean & 15.4 & 5,151 & 3,281 & 3.59 & $5.9 \%$ & $14.5 \%$ & $53.1 \%$ \\
\hline Standard deviation & 11.0 & 14,781 & 7,943 & 3.93 & $17.6 \%$ & $55.9 \%$ & $26.8 \%$ \\
\hline $25^{\text {th }}$ percentile & 7.0 & 263 & 200 & 1.48 & $4.4 \%$ & $-14.6 \%$ & $33.4 \%$ \\
\hline $50^{\text {th }}$ percentile & 12.0 & 908 & 702 & 2.39 & $9.4 \%$ & $12.5 \%$ & $46.7 \%$ \\
\hline $75^{\text {th }}$ percentile & 22.0 & 3,141 & 2,402 & 4.03 & $14.2 \%$ & $41.0 \%$ & $65.3 \%$ \\
\hline
\end{tabular}

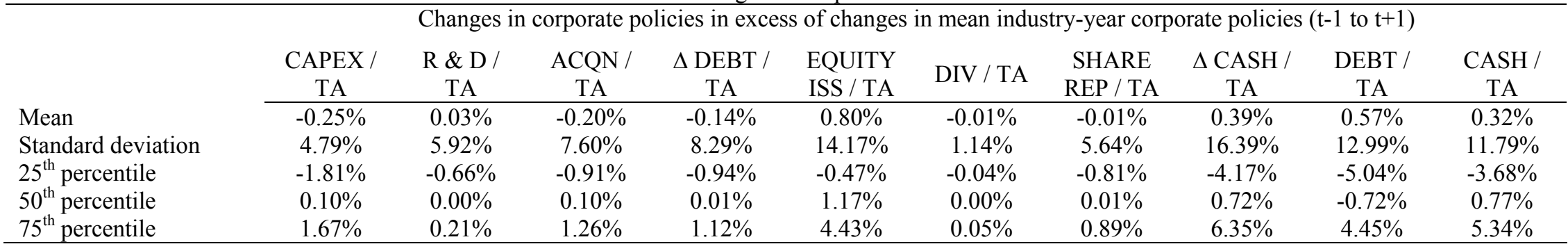




\section{Table 4}

The Effect of Analyst Preferences on Corporate Policies

This table presents the results of regressions of future changes in corporate policies on past levels of analyst preferences. The regression equation is:

$$
\left(\mathrm{CPV}_{\mathrm{i}, t+1}-\mathrm{CPV}_{\mathrm{i},-1-1}\right)=\alpha+\beta \cdot \mathrm{APV}_{\mathrm{j}}+\gamma \cdot \mathrm{X}_{\mathrm{i}, \mathrm{-1}-1}+\varepsilon_{\mathrm{i}, \mathrm{t}, \mathrm{j}} \text {, }
$$

where $\mathrm{CPV}$ is a corporate policy variable, $\mathrm{APV}$ is an analyst preference variable, $\mathrm{X}$ are control variables, and the unit of observation (i,t,j) is a firm-year-analyst triple. The sample comprises 15,158 analyst-year-firm observations corresponding to 1,137 unique analysts and 4,182 unique firms between 1987 and 2009 . The analysts in the sample disappear and terminate coverage of all firms on their coverage list. The firms in the sample are publicly traded U.S. operating firms excluding financials and utilities. All variables are defined in Appendix Table 1. The economic magnitude of analyst preferences is computed as the effect of a one-standard deviation increase in the analyst preference variable and expressed as a percent of total assets. An analyst is deemed to disappear in year $t$ if he covers some firms in year $\mathrm{t}-1$ and he does not cover any firm in year $\mathrm{t}+1$. Changes in corporate policy variables are measured in excess of changes in mean industry-year corporate policy variables and are expressed as a percent of total assets. Levels of corporate policy variables are measured analogously. Changes in corporate policy variables are measured from the year before the analyst disappears (t-1) to the year thereafter $(t+1)$. Levels of corporate policy variables are measured at two years before the analyst disappears ( $\mathrm{t}-2)$. Analyst preferences and control variables are measured at the year before the analyst disappears ( $\mathrm{t}-1)$. Standard errors are clustered by firm. ${ }^{* * *},{ }^{* *}$, and * indicate statistical significance at the $1 \%, 5 \%$, and $10 \%$ levels, respectively. 


\begin{tabular}{|c|c|c|c|c|c|c|c|c|c|c|}
\hline \multirow[b]{3}{*}{ Analyst preference } & \multicolumn{10}{|c|}{ Changes in corporate policies in excess of changes in mean industry-year corporate policies $(t-1$ to $t+1)$} \\
\hline & $\begin{array}{c}\text { CAPEX / } \\
\text { TA }\end{array}$ & $\begin{array}{c}\mathrm{R} \& \mathrm{D} / \\
\mathrm{TA}\end{array}$ & $\begin{array}{c}\text { ACQN / } \\
\text { TA }\end{array}$ & $\begin{array}{c}\Delta \text { DEBT / } \\
\text { TA }\end{array}$ & $\begin{array}{l}\text { EQUITY } \\
\text { ISS / TA }\end{array}$ & DIV / TA & $\begin{array}{c}\text { SHARE } \\
\text { REP / TA }\end{array}$ & $\begin{array}{c}\Delta \mathrm{CASH} / \\
\mathrm{TA}\end{array}$ & $\begin{array}{c}\text { DEBT / } \\
\text { TA }\end{array}$ & $\begin{array}{c}\text { CASH / } \\
\text { TA }\end{array}$ \\
\hline & $\begin{array}{c}-23.72 * * * \\
(-4.89)\end{array}$ & $\begin{array}{c}-29.49 * * \\
(-2.09)\end{array}$ & $\begin{array}{c}-73.42 * * * \\
(-8.96)\end{array}$ & $\begin{array}{c}-67.71 * * * \\
(-6.58)\end{array}$ & $\begin{array}{c}-81.35 * * * \\
(-6.92)\end{array}$ & $\begin{array}{c}-37.64 * * * \\
(-5.41)\end{array}$ & $\begin{array}{c}-70.78 * * * \\
(-8.10)\end{array}$ & $\begin{array}{c}-111.09^{* * *} \\
(-7.80)\end{array}$ & $\begin{array}{c}-34.69 * * * \\
(-6.84)\end{array}$ & $\begin{array}{c}-35.43 * * * \\
(-6.39)\end{array}$ \\
\hline $\begin{array}{l}\text { Excess corporate policy } \\
(\mathrm{t}-2)\end{array}$ & $\begin{array}{c}-0.24 * * * \\
(-17.96)\end{array}$ & $\begin{array}{c}0.01 \\
(0.65)\end{array}$ & $\begin{array}{c}-0.05 * * * \\
(-3.08)\end{array}$ & $\begin{array}{c}0.02 \\
(0.88)\end{array}$ & $\begin{array}{c}-0.08 * * * \\
(-5.42)\end{array}$ & $\begin{array}{c}-0.08 * * * \\
(-3.78)\end{array}$ & $\begin{array}{c}-0.21 * * * \\
(-7.02)\end{array}$ & $\begin{array}{c}0.18 * * * \\
(6.80)\end{array}$ & $\begin{array}{c}-0.16^{* * *} \\
(-14.49)\end{array}$ & $\begin{array}{l}-0.15 * * * \\
(-16.16)\end{array}$ \\
\hline Size $(\mathrm{t}-1)$ & $\begin{array}{c}0.08 * * * \\
(2.96)\end{array}$ & $\begin{array}{c}-0.02 \\
(-0.48)\end{array}$ & $\begin{array}{c}-0.15 * * * \\
(-3.80)\end{array}$ & $\begin{array}{l}-0.06 \\
(-1.26)\end{array}$ & $\begin{array}{l}-0.15 * * \\
(-2.04)\end{array}$ & $\begin{array}{l}0.01 * * \\
(2.06)\end{array}$ & $\begin{array}{c}0.05 \\
(1.42)\end{array}$ & $\begin{array}{l}-0.16 \\
(-1.42)\end{array}$ & $\begin{array}{c}0.03 \\
(0.26)\end{array}$ & $\begin{array}{l}0.15^{*} \\
(1.67)\end{array}$ \\
\hline Market-to-book (t-1) & $\begin{array}{c}-0.07 * * * \\
(-4.95)\end{array}$ & $\begin{array}{c}-0.08 * * * \\
(-3.25)\end{array}$ & $\begin{array}{c}0.01 \\
(0.67)\end{array}$ & $\begin{array}{l}-0.05 * * \\
(-2.01)\end{array}$ & $\begin{array}{c}0.19 * * * \\
(4.06)\end{array}$ & $\begin{array}{c}-0.00 \\
(-0.61)\end{array}$ & $\begin{array}{c}-0.07 * * * \\
(-2.94)\end{array}$ & $\begin{array}{l}-0.00 \\
(-0.04)\end{array}$ & $\begin{array}{c}-0.03 \\
(-0.51)\end{array}$ & $\begin{array}{c}-0.02 \\
(-0.40)\end{array}$ \\
\hline $\begin{array}{l}\text { Cash flow-to- } \\
\text { total assets (t-1) }\end{array}$ & $\begin{array}{l}0.64 * \\
(1.82)\end{array}$ & $\begin{array}{c}3.01 * * * \\
(2.93)\end{array}$ & $\begin{array}{c}1.09 * * \\
(2.31)\end{array}$ & $\begin{array}{c}0.09 \\
(0.18)\end{array}$ & $\begin{array}{l}-2.08 \\
(-1.23)\end{array}$ & $\begin{array}{c}0.04 \\
(0.86)\end{array}$ & $\begin{array}{c}-0.19 \\
(-0.56)\end{array}$ & $\begin{array}{c}-6.84 * * * \\
(-3.17)\end{array}$ & $\begin{array}{c}-4.24 * * * \\
(-2.95)\end{array}$ & $\begin{array}{l}-1.75 \\
(-1.38)\end{array}$ \\
\hline Stock returns $(\mathrm{t}-1)$ & $\begin{array}{l}1.26 * * * \\
(11.85)\end{array}$ & $\begin{array}{c}-0.00 \\
(-0.03)\end{array}$ & $\begin{array}{c}0.06 \\
(0.41)\end{array}$ & $\begin{array}{c}0.59 * * * \\
(3.46)\end{array}$ & $\begin{array}{c}-2.73 * * * \\
(-7.88)\end{array}$ & $\begin{array}{c}0.05 * * \\
(2.45)\end{array}$ & $\begin{array}{c}0.92 * * * \\
(7.61)\end{array}$ & $\begin{array}{c}-2.28 * * * \\
(-4.92)\end{array}$ & $\begin{array}{c}0.08 \\
(0.30)\end{array}$ & $\begin{array}{c}-1.37 * * * \\
(-4.19)\end{array}$ \\
\hline Volatility (t-1) & $\begin{array}{c}-0.47 * * \\
(-2.10)\end{array}$ & $\begin{array}{c}2.25 * * * \\
(4.64)\end{array}$ & $\begin{array}{c}0.20 \\
(0.60)\end{array}$ & $\begin{array}{c}0.02 \\
(0.05)\end{array}$ & $\begin{array}{c}-0.21 \\
(-0.31)\end{array}$ & $\begin{array}{l}-0.11 * * \\
(-2.39)\end{array}$ & $\begin{array}{c}0.04 \\
(0.14)\end{array}$ & $\begin{array}{c}-3.73 * * * \\
(-3.23)\end{array}$ & $\begin{array}{c}-0.32 \\
(-0.42)\end{array}$ & $\begin{array}{c}3.83 * * * \\
(4.84)\end{array}$ \\
\hline Constant & $\begin{array}{c}0.12 \\
(0.44)\end{array}$ & $\begin{array}{c}-0.76 \\
(-1.58)\end{array}$ & $\begin{array}{c}-1.31 * * * \\
(-3.16)\end{array}$ & $\begin{array}{c}1.43 * * * \\
(2.93)\end{array}$ & $\begin{array}{c}3.38 * * * \\
(4.49)\end{array}$ & $\begin{array}{c}0.00 \\
(0.02)\end{array}$ & $\begin{array}{c}-0.26 \\
(-0.79)\end{array}$ & $\begin{array}{c}3.62 * * * \\
(2.99)\end{array}$ & $\begin{array}{l}1.20 \\
(1.32)\end{array}$ & $\begin{array}{c}0.18 \\
(0.20)\end{array}$ \\
\hline $\begin{array}{l}\text { Observations } \\
\text { Adjusted } \mathrm{R}^{2}\end{array}$ & $\begin{array}{c}14,215 \\
0.108\end{array}$ & $\begin{array}{c}14,215 \\
0.014\end{array}$ & $\begin{array}{c}14,215 \\
0.013\end{array}$ & $\begin{array}{c}14,215 \\
0.006\end{array}$ & $\begin{array}{c}14,215 \\
0.037\end{array}$ & $\begin{array}{c}14,215 \\
0.018\end{array}$ & $\begin{array}{c}14,215 \\
0.047\end{array}$ & $\begin{array}{c}14,215 \\
0.041\end{array}$ & $\begin{array}{c}14,215 \\
0.048\end{array}$ & $\begin{array}{c}14,215 \\
0.078\end{array}$ \\
\hline Economic magnitude & $-0.28 \%$ & $-0.26 \%$ & $-0.69 \%$ & $-0.50 \%$ & $-1.29 \%$ & $-0.07 \%$ & $-0.52 \%$ & $-1.46 \%$ & $-0.98 \%$ & $-0.84 \%$ \\
\hline
\end{tabular}




\section{Table 5}

The Effect of Analyst Preferences on Corporate Policies Accounting for Both the Analyst that Disappears and Other Analysts

This table presents the same regressions as Table 4 with one exception: the change in the mean of the preferences of all analysts is used instead of the preferences of the analyst that disappears. Only selected results are tabulated.

Changes in corporate policies in excess of changes in mean industry-year corporate policies

\begin{tabular}{lccccccccccc} 
& CAPEX / & R \& D / & ACQN / & $\Delta$ DEBT / & EQUITY & \multirow{2}{*}{ DIV / TA } & SHARE & $\Delta$ CASH / & DEBT / & CASH / \\
& TA & TA & TA & TA & ISS / TA & & & TA & TA & TA \\
\cline { 2 - 10 } Change in the preference & $72.44^{* * *}$ & $220.91^{* * *}$ & $249.67^{* * *}$ & $250.84^{* * *}$ & $244.09^{* * *}$ & $128.20^{* * *}$ & $231.59^{* * *}$ & $307.67^{* * *}$ & $223.31^{* * *}$ & $170.99^{* * *}$ \\
of all analysts & $(2.61)$ & $(2.82)$ & $(5.56)$ & $(5.15)$ & $(3.53)$ & $(3.91)$ & $(5.44)$ & $(4.54)$ & $(8.52)$ & $(5.68)$ \\
Control variables? & Yes & Yes & Yes & Yes & Yes & Yes & Yes & Yes & Yes & Yes \\
Observations & 13,038 & 13,038 & 13,038 & 13,038 & 13,038 & 13,038 & 13,038 & 13,038 & 13,038 & 13,038 \\
Adjusted R & & 0.107 & 0.017 & 0.008 & 0.004 & 0.035 & 0.017 & 0.046 & 0.030 & 0.048 & 0.076 \\
Economic magnitude & $0.12 \%$ & $0.32 \%$ & $0.40 \%$ & $0.33 \%$ & $0.63 \%$ & $0.04 \%$ & $0.27 \%$ & $0.73 \%$ & $0.97 \%$ & $0.64 \%$ \\
\hline
\end{tabular}




\section{Table 6}

The Monotonicity and Symmetry of the Effect of Analyst Preferences on Corporate Policies

This table presents the same regressions as Table 4 with one exception: dummy variables for quintiles of analyst preferences are used instead of analyst preferences. The omitted dummy variable is the dummy variable for the third quintile of analyst preferences. Only selected results are tabulated.

\begin{tabular}{|c|c|c|c|c|c|c|c|c|c|c|}
\hline \multirow[b]{3}{*}{$\begin{array}{l}\text { Analyst preference } \\
\text { quintile } 5 \text { (likes) }\end{array}$} & \multicolumn{10}{|c|}{ Changes in corporate policies in excess of changes in mean industry-year corporate policies } \\
\hline & $\begin{array}{l}\text { CAPEX / } \\
\text { TA } \\
\end{array}$ & $\begin{array}{c}\mathrm{R} \& \mathrm{D} / \\
\mathrm{TA}\end{array}$ & $\begin{array}{c}\mathrm{ACQN} / \\
\mathrm{TA}\end{array}$ & $\begin{array}{l}\Delta \mathrm{DEBT} / \\
\mathrm{TA}\end{array}$ & $\begin{array}{l}\text { EQUITY } \\
\text { ISS / TA }\end{array}$ & DIV / TA & $\begin{array}{l}\text { SHARE } \\
\text { REP / TA }\end{array}$ & $\begin{array}{l}\Delta \mathrm{CASH} / \\
\mathrm{TA}\end{array}$ & $\begin{array}{l}\text { DEBT / } \\
\text { TA }\end{array}$ & $\begin{array}{c}\text { CASH / } \\
\text { TA }\end{array}$ \\
\hline & $\begin{array}{c}-0.28 * * \\
(-2.13)\end{array}$ & $\begin{array}{l}-0.29^{*} \\
(-1.71)\end{array}$ & $\begin{array}{c}-0.96 * * * \\
(-4.64)\end{array}$ & $\begin{array}{c}-0.95 * * * \\
(-3.92)\end{array}$ & $\begin{array}{c}-2.53 * * * \\
(-7.34)\end{array}$ & $\begin{array}{c}-0.03 \\
(-1.07)\end{array}$ & $\begin{array}{c}-0.58 * * * \\
(-4.19)\end{array}$ & $\begin{array}{c}-2.47 * * * \\
(-5.63)\end{array}$ & $\begin{array}{c}-1.27 * * * \\
(-3.60)\end{array}$ & $\begin{array}{c}-1.21 * * * \\
(-3.76)\end{array}$ \\
\hline $\begin{array}{l}\text { Analyst preference } \\
\text { quintile } 4\end{array}$ & $\begin{array}{c}-0.08 \\
(-0.71)\end{array}$ & $\begin{array}{c}-0.06 \\
(-0.59)\end{array}$ & $\begin{array}{l}-0.38^{*} \\
(-1.92)\end{array}$ & $\begin{array}{l}-0.35^{*} \\
(-1.69)\end{array}$ & $\begin{array}{c}-0.24 \\
(-0.93)\end{array}$ & $\begin{array}{c}0.01 \\
(0.42)\end{array}$ & $\begin{array}{c}-0.19 \\
(-1.61)\end{array}$ & $\begin{array}{c}0.07 \\
(0.21)\end{array}$ & $\begin{array}{l}-0.84 * * \\
(-2.55)\end{array}$ & $\begin{array}{c}-0.25 \\
(-0.90)\end{array}$ \\
\hline $\begin{array}{l}\text { Analyst preference } \\
\text { quintile } 2\end{array}$ & $\begin{array}{c}0.29 * * * \\
(2.78)\end{array}$ & $\begin{array}{c}0.00 \\
(0.00)\end{array}$ & $\begin{array}{c}0.48 * * * \\
(2.67)\end{array}$ & $\begin{array}{l}0.38 * \\
(1.90)\end{array}$ & $\begin{array}{c}0.23 \\
(0.92)\end{array}$ & $\begin{array}{l}0.04 * \\
(1.66)\end{array}$ & $\begin{array}{c}0.34 * * \\
(2.52)\end{array}$ & $\begin{array}{l}0.67 * * \\
(2.05)\end{array}$ & $\begin{array}{c}-0.01 \\
(-0.04)\end{array}$ & $\begin{array}{c}0.20 \\
(0.79)\end{array}$ \\
\hline $\begin{array}{l}\text { Analyst preference } \\
\text { quintile } 1 \text { (dislikes) }\end{array}$ & $\begin{array}{c}0.44 * * * \\
(3.86)\end{array}$ & $\begin{array}{c}0.39 * * * \\
(2.91)\end{array}$ & $\begin{array}{c}0.83 * * * \\
(4.35)\end{array}$ & $\begin{array}{c}0.32 \\
(1.56)\end{array}$ & $\begin{array}{c}0.57 * * \\
(2.08)\end{array}$ & $\begin{array}{c}0.13 * * * \\
(4.54)\end{array}$ & $\begin{array}{c}0.60 * * * \\
(4.50)\end{array}$ & $\begin{array}{c}1.29 * * * \\
(3.54)\end{array}$ & $\begin{array}{c}1.46 * * * \\
(3.93)\end{array}$ & $\begin{array}{c}0.76 * * * \\
(2.81)\end{array}$ \\
\hline
\end{tabular}


Table 7

The Effect of Analyst Preferences on Corporate Policies Conditional Upon Various Additional Analyst Characteristics and Firm Characteristics

This table presents the same regressions as Table 4 with one exception: analyst preferences are interacted with various conditioning variables. In Panel A, the conditioning variable is analyst attention, which is captured using the number of firms covered by the analyst that disappears. In Panel B, the conditioning variable is firm age, which is captured using the number of years the firm has been publicly traded. In Panel C, the conditioning variable is firm investment opportunities and valuation both of which are captured using market-to-book. Firm age and market-to-book are measured as natural logarithms. All conditioning variables are measured at the year before the analyst disappears. Only selected results are tabulated. 
Panel A: Conditional Upon Analyst Attention

Changes in corporate policies in excess of changes in mean industry-year corporate policies

\begin{tabular}{|c|c|c|c|c|c|c|c|c|c|c|}
\hline & $\begin{array}{c}\text { CAPEX / } \\
\text { TA }\end{array}$ & $\begin{array}{c}\mathrm{R} \& \mathrm{D} / \\
\mathrm{TA}\end{array}$ & $\begin{array}{c}\mathrm{ACQN} / \\
\mathrm{TA}\end{array}$ & $\begin{array}{c}\Delta \mathrm{DEBT} / \\
\mathrm{TA}\end{array}$ & $\begin{array}{l}\text { EQUITY } \\
\text { ISS / TA }\end{array}$ & $\mathrm{DIV} / \mathrm{TA}$ & $\begin{array}{l}\text { SHARE } \\
\text { REP / TA }\end{array}$ & $\begin{array}{c}\Delta \mathrm{CASH} / \\
\mathrm{TA}\end{array}$ & $\begin{array}{l}\text { DEBT / } \\
\text { TA }\end{array}$ & $\begin{array}{l}\mathrm{CASH} / \\
\mathrm{TA}\end{array}$ \\
\hline Analyst preference & $\begin{array}{c}-69.42 * * * \\
(-2.68)\end{array}$ & $\begin{array}{c}-145.60^{*} \\
(-1.85)\end{array}$ & $\begin{array}{l}-44.03 \\
(-0.84)\end{array}$ & $\begin{array}{c}-195.98 * * * \\
(-3.98)\end{array}$ & $\begin{array}{c}-213.45^{* * *} \\
(-2.89)\end{array}$ & $\begin{array}{c}-124.42 * * * \\
(-3.87)\end{array}$ & $\begin{array}{c}-155.51 * * * \\
(-3.29)\end{array}$ & $\begin{array}{c}-126.15 \\
(-1.60)\end{array}$ & $\begin{array}{l}-28.49 \\
(-0.98)\end{array}$ & $\begin{array}{c}-120.57^{* * *} \\
(-3.77)\end{array}$ \\
\hline Analyst attention & $\begin{array}{c}-0.14 \\
(-1.04)\end{array}$ & $\begin{array}{c}-0.28 \\
(-1.55)\end{array}$ & $\begin{array}{c}-0.24 \\
(-0.45)\end{array}$ & $\begin{array}{c}-0.74 * * \\
(-2.46)\end{array}$ & $\begin{array}{l}0.43^{* *} \\
(2.07)\end{array}$ & $\begin{array}{c}-0.01 \\
(-0.63)\end{array}$ & $\begin{array}{c}-0.00 \\
(-0.00)\end{array}$ & $\begin{array}{l}0.67^{*} \\
(1.95)\end{array}$ & $\begin{array}{c}0.14 \\
(0.50)\end{array}$ & $\begin{array}{c}-1.49 * * \\
(-2.30)\end{array}$ \\
\hline $\begin{array}{l}\text { Analyst preference } \\
\times \text { Analyst attention }\end{array}$ & $\begin{array}{l}16.23^{*} \\
(1.86)\end{array}$ & $\begin{array}{l}42.58 \\
(1.50)\end{array}$ & $\begin{array}{l}-10.73 \\
(-0.57)\end{array}$ & $\begin{array}{c}46.15^{* * * *} \\
(2.68)\end{array}$ & $\begin{array}{c}49.97^{*} \\
(1.86)\end{array}$ & $\begin{array}{c}31.25^{* * *} \\
(2.84)\end{array}$ & $\begin{array}{l}31.23^{*} \\
(1.88)\end{array}$ & $\begin{array}{c}5.72 \\
(0.20)\end{array}$ & $\begin{array}{l}-2.28 \\
(-0.22)\end{array}$ & $\begin{array}{c}31.63 * * * \\
(2.74)\end{array}$ \\
\hline
\end{tabular}

Panel B: Conditional Upon Firm Age

Changes in corporate policies in excess of changes in mean industry-year corporate policies

\begin{tabular}{|c|c|c|c|c|c|c|c|c|c|c|}
\hline & $\begin{array}{l}\text { CAPEX / } \\
\text { TA }\end{array}$ & $\begin{array}{c}\mathrm{R} \& \mathrm{D} / \\
\mathrm{TA}\end{array}$ & $\begin{array}{c}\mathrm{ACQN} / \\
\mathrm{TA}\end{array}$ & $\begin{array}{l}\Delta \mathrm{DEBT} / \\
\mathrm{TA}\end{array}$ & $\begin{array}{l}\text { EQUITY } \\
\text { ISS / TA }\end{array}$ & $\mathrm{DIV} / \mathrm{TA}$ & $\begin{array}{l}\text { SHARE } \\
\text { REP / TA }\end{array}$ & $\begin{array}{c}\Delta \mathrm{CASH} / \\
\mathrm{TA} \\
\end{array}$ & $\begin{array}{c}\text { DEBT / } \\
\text { TA }\end{array}$ & $\begin{array}{c}\mathrm{CASH} / \\
\mathrm{TA}\end{array}$ \\
\hline Analyst preference & $\begin{array}{c}-63.97 * * * \\
(-4.16)\end{array}$ & $\begin{array}{l}-60.82 \\
(-1.55)\end{array}$ & $\begin{array}{c}-113.19 * * * \\
(-4.95)\end{array}$ & $\begin{array}{c}-140.01 * * * \\
(-5.13)\end{array}$ & $\begin{array}{c}-134.31 * * * \\
(-4.05)\end{array}$ & $\begin{array}{c}-59.12 * * * \\
(-3.39)\end{array}$ & $\begin{array}{c}-90.41 * * * \\
(-4.37)\end{array}$ & $\begin{array}{c}-306.57 * * * \\
(-6.64)\end{array}$ & $\begin{array}{c}-54.01 * * * \\
(-3.90)\end{array}$ & $\begin{array}{c}-82.80 * * * \\
(-5.12)\end{array}$ \\
\hline Firm age & $\begin{array}{l}-0.15^{*} \\
(-1.76)\end{array}$ & $\begin{array}{c}-0.38 * * * \\
(-3.15)\end{array}$ & $\begin{array}{c}0.69 * * * \\
(2.72)\end{array}$ & $\begin{array}{c}-0.22 \\
(-1.20)\end{array}$ & $\begin{array}{l}-0.33 * * \\
(-2.24)\end{array}$ & $\begin{array}{c}0.00 \\
(0.07)\end{array}$ & $\begin{array}{l}-0.15 * * \\
(-2.10)\end{array}$ & $\begin{array}{c}0.75 * * * \\
(3.00)\end{array}$ & $\begin{array}{c}-0.28 \\
(-1.45)\end{array}$ & $\begin{array}{c}-1.16 * * * \\
(-3.30)\end{array}$ \\
\hline $\begin{array}{l}\text { Analyst preference } \\
\times \text { Firm age }\end{array}$ & $\begin{array}{c}15.96^{* * * *} \\
(3.16)\end{array}$ & $\begin{array}{l}15.85 \\
(1.07)\end{array}$ & $\begin{array}{c}17.44 * * \\
(2.08)\end{array}$ & $\begin{array}{c}29.26^{* * *} \\
(2.88)\end{array}$ & $\begin{array}{c}25.10 * * \\
(2.05)\end{array}$ & $\begin{array}{c}8.28 \\
(1.50)\end{array}$ & $\begin{array}{c}8.75 \\
(1.09)\end{array}$ & $\begin{array}{c}90.65^{* * * *} \\
(5.25)\end{array}$ & $\begin{array}{l}7.97 * \\
(1.73)\end{array}$ & $\begin{array}{c}21.10^{* * *} \\
(3.65)\end{array}$ \\
\hline
\end{tabular}

Changes in corporate policies in excess of changes in mean industry-year corporate policies

\begin{tabular}{|c|c|c|c|c|c|c|c|c|c|c|}
\hline & \multicolumn{10}{|c|}{ Changes in corporate policies in excess of changes in mean industry-year corporate policies } \\
\hline & $\begin{array}{c}\text { CAPEX / } \\
\text { TA }\end{array}$ & $\begin{array}{c}\mathrm{R} \& \mathrm{D} / \\
\mathrm{TA}\end{array}$ & $\begin{array}{c}\text { ACQN / } \\
\text { TA }\end{array}$ & $\begin{array}{c}\Delta \mathrm{DEBT} / \\
\mathrm{TA}\end{array}$ & $\begin{array}{l}\text { EQUITY } \\
\text { ISS / TA }\end{array}$ & DIV / TA & $\begin{array}{l}\text { SHARE } \\
\text { REP / TA }\end{array}$ & $\begin{array}{c}\Delta \mathrm{CASH} / \\
\mathrm{TA}\end{array}$ & $\begin{array}{c}\text { DEBT / } \\
\text { TA }\end{array}$ & $\begin{array}{c}\text { CASH / } \\
\text { TA }\end{array}$ \\
\hline Analyst preference & $\begin{array}{l}-11.15 \\
(-1.48)\end{array}$ & $\begin{array}{c}2.04 \\
(0.11)\end{array}$ & $\begin{array}{c}-80.57 * * * \\
(-7.08)\end{array}$ & $\begin{array}{c}-73.11 * * * \\
(-5.01)\end{array}$ & $\begin{array}{c}-59.83 * * * \\
(-3.65)\end{array}$ & $\begin{array}{l}-10.76 \\
(-1.12)\end{array}$ & $\begin{array}{c}-58.34 * * * \\
(-4.51)\end{array}$ & $\begin{array}{c}-83.55^{* * *} \\
(-4.00)\end{array}$ & $\begin{array}{c}-22.97 * * * \\
(-3.23)\end{array}$ & $\begin{array}{c}-25.21 * * * \\
(-3.13)\end{array}$ \\
\hline Market-to-book & $\begin{array}{c}-0.00 \\
(-0.07)\end{array}$ & $\begin{array}{l}-0.02 \\
(-0.73)\end{array}$ & $\begin{array}{c}0.07 \\
(1.00)\end{array}$ & $\begin{array}{c}-0.09 \\
(-1.42)\end{array}$ & $\begin{array}{c}0.24 * * * \\
(4.43)\end{array}$ & $\begin{array}{l}-0.01 * \\
(-1.71)\end{array}$ & $\begin{array}{c}-0.08 * * * \\
(-2.67)\end{array}$ & $\begin{array}{c}-0.05 \\
(-0.67)\end{array}$ & $\begin{array}{c}0.01 \\
(0.15)\end{array}$ & $\begin{array}{c}0.14 \\
(1.32)\end{array}$ \\
\hline $\begin{array}{l}\text { Analyst preference } \\
\times \text { Market-to-book }\end{array}$ & $\begin{array}{l}-4.64 * * \\
(-1.99)\end{array}$ & $\begin{array}{l}-6.31 * * \\
(-2.16)\end{array}$ & $\begin{array}{l}2.15 \\
(0.91) \\
\end{array}$ & $\begin{array}{l}1.84 \\
(0.55)\end{array}$ & $\begin{array}{c}-4.96 \\
(-1.39)\end{array}$ & $\begin{array}{c}-9.13 * * * \\
(-2.62)\end{array}$ & $\begin{array}{c}-3.69 \\
(-0.93)\end{array}$ & $\begin{array}{l}-6.93 * \\
(-1.73) \\
\end{array}$ & $\begin{array}{l}-3.24 * * \\
(-2.01)\end{array}$ & $\begin{array}{c}-2.55 \\
(-1.41)\end{array}$ \\
\hline
\end{tabular}


Table 8

Robustness Tests of the Effect of Analyst Preferences on Corporate Policies

This table presents the same regressions as Table 4 with the following exceptions for each panel. In Panel A, the sample comprises 747 analyst-year-firm observations corresponding to 60 unique analysts that disappear because of broker closures or broker mergers and 606 unique firms between 1994 and 2008 . In Panel B, all variables except analyst preferences are moved back two years. In other words, the dependent variables are measured from three years before the analyst disappears to one year before, and the independent variables are measured at three years before the analyst disappears. In Panel C, analyst preferences are interacted with a short estimation period dummy variable, and this interaction variable is used as a control variable alongside the short estimation period dummy variable. The short estimation period dummy variable equals one if the analyst preference estimation period is below the median and it equals zero otherwise. In Panel D, a control variable for broker preferences is also used. Only selected results are tabulated.

\begin{tabular}{|c|c|c|c|c|c|c|c|c|c|c|}
\hline \multicolumn{11}{|c|}{ Panel A: Using Analyst Disappearances Caused By Broker Closures and Broker Mergers } \\
\hline & \multicolumn{10}{|c|}{ Changes in corporate policies in excess of changes in mean industry-year corporate policies } \\
\hline & $\begin{array}{c}\text { CAPEX / } \\
\text { TA }\end{array}$ & $\begin{array}{c}\mathrm{R} \& \mathrm{D} / \\
\mathrm{TA}\end{array}$ & $\begin{array}{c}\mathrm{ACQN} / \\
\mathrm{TA} \\
\end{array}$ & $\begin{array}{c}\Delta \mathrm{DEBT} / \\
\mathrm{TA}\end{array}$ & $\begin{array}{l}\text { EQUITY } \\
\text { ISS / TA }\end{array}$ & DIV / TA & $\begin{array}{c}\text { SHARE } \\
\text { REP / TA }\end{array}$ & $\begin{array}{c}\Delta \mathrm{CASH} / \\
\mathrm{TA}\end{array}$ & $\begin{array}{c}\text { DEBT / } \\
\text { TA }\end{array}$ & $\begin{array}{c}\text { CASH / } \\
\text { TA }\end{array}$ \\
\hline Analyst preference & $\begin{array}{c}-7.75 \\
(-0.34)\end{array}$ & $\begin{array}{l}32.19 \\
(1.03)\end{array}$ & $\begin{array}{c}-67.42 * * \\
(-2.39)\end{array}$ & $\begin{array}{l}-47.09 \\
(-1.22)\end{array}$ & $\begin{array}{c}-174.77 * * * \\
(-3.71)\end{array}$ & $\begin{array}{c}-89.53 * * * \\
(-3.01)\end{array}$ & $\begin{array}{l}-36.99 \\
(-1.33)\end{array}$ & $\begin{array}{c}-184.25 * * \\
(-2.44)\end{array}$ & $\begin{array}{c}-60.83 * * * \\
(-3.65)\end{array}$ & $\begin{array}{c}-47.29 * \\
(-1.72)\end{array}$ \\
\hline Control variables? & Yes & Yes & Yes & Yes & Yes & Yes & Yes & Yes & Yes & Yes \\
\hline Observations & 707 & 707 & 707 & 707 & 707 & 707 & 707 & 707 & 707 & 707 \\
\hline Adjusted $\mathrm{R}^{2}$ & 0.130 & 0.029 & 0.007 & 0.010 & 0.090 & 0.018 & 0.147 & 0.019 & 0.054 & 0.097 \\
\hline Economic magnitude & $-0.09 \%$ & $0.28 \%$ & $-0.63 \%$ & $-0.35 \%$ & $-2.78 \%$ & $-0.16 \%$ & $-0.27 \%$ & $-2.43 \%$ & $-1.72 \%$ & $-1.13 \%$ \\
\hline \multicolumn{11}{|c|}{ Panel B: Placebo Test Before the Analyst Disappears } \\
\hline \multicolumn{11}{|c|}{ Changes in corporate policies in excess of changes in mean industry-year corporate policies } \\
\hline & $\begin{array}{c}\text { CAPEX / } \\
\text { TA }\end{array}$ & $\begin{array}{c}\mathrm{R} \& \mathrm{D} / \\
\mathrm{TA}\end{array}$ & $\begin{array}{c}\mathrm{ACQN} / \\
\mathrm{TA}\end{array}$ & $\begin{array}{c}\Delta \mathrm{DEBT} / \\
\mathrm{TA}\end{array}$ & $\begin{array}{l}\text { EQUITY } \\
\text { ISS / TA }\end{array}$ & DIV / TA & $\begin{array}{c}\text { SHARE } \\
\text { REP / TA }\end{array}$ & $\begin{array}{c}\Delta \mathrm{CASH} / \\
\mathrm{TA}\end{array}$ & $\begin{array}{c}\text { DEBT / } \\
\text { TA }\end{array}$ & $\begin{array}{c}\mathrm{CASH} / \\
\text { TA }\end{array}$ \\
\hline Analyst preference & $\begin{array}{c}-0.87 \\
(-0.14)\end{array}$ & $\begin{array}{c}-2.14 \\
(-0.16)\end{array}$ & $\begin{array}{c}4.79 \\
(0.44)\end{array}$ & $\begin{array}{c}27.93 * * * \\
(2.75)\end{array}$ & $\begin{array}{l}11.35 \\
(0.83)\end{array}$ & $\begin{array}{l}12.56^{*} \\
(1.78)\end{array}$ & $\begin{array}{c}8.34 \\
(0.93)\end{array}$ & $\begin{array}{c}31.83 * * \\
(2.16)\end{array}$ & $\begin{array}{c}14.32 * * * \\
(2.85)\end{array}$ & $\begin{array}{c}18.34 * * * \\
(2.84)\end{array}$ \\
\hline Economic magnitude & $-0.01 \%$ & $-0.02 \%$ & $0.04 \%$ & $0.21 \%$ & $0.18 \%$ & $0.02 \%$ & $0.06 \%$ & $0.42 \%$ & $0.41 \%$ & $0.44 \%$ \\
\hline
\end{tabular}


Panel C: Conditional Upon Preference Estimation Period Length

Changes in corporate policies in excess of changes in mean industry-year corporate policies

\begin{tabular}{|c|c|c|c|c|c|c|c|c|c|c|}
\hline & $\begin{array}{l}\text { CAPEX / } \\
\text { TA }\end{array}$ & $\begin{array}{l}\mathrm{R} \& \mathrm{D} / \\
\mathrm{TA}\end{array}$ & $\begin{array}{c}\mathrm{ACQN} / \\
\mathrm{TA}\end{array}$ & $\begin{array}{l}\Delta \mathrm{DEBT} / \\
\mathrm{TA}\end{array}$ & $\begin{array}{l}\text { EQUITY } \\
\text { ISS / TA }\end{array}$ & DIV / TA & $\begin{array}{l}\text { SHARE } \\
\text { REP / TA }\end{array}$ & $\begin{array}{c}\Delta \mathrm{CASH} / \\
\mathrm{TA}\end{array}$ & $\begin{array}{l}\text { DEBT / } \\
\text { TA }\end{array}$ & $\begin{array}{c}\mathrm{CASH} / \\
\mathrm{TA}\end{array}$ \\
\hline Analyst preference & $\begin{array}{c}-26.23 * * \\
(-2.55)\end{array}$ & $\begin{array}{c}-33.74^{*} \\
(-1.70)\end{array}$ & $\begin{array}{c}-53.08 * * * \\
(-3.57)\end{array}$ & $\begin{array}{c}-42.54 * * \\
(-2.41)\end{array}$ & $\begin{array}{c}-107.93 * * * \\
(-5.50)\end{array}$ & $\begin{array}{c}-40.01 * * \\
(-2.57)\end{array}$ & $\begin{array}{c}-78.86 * * * \\
(-4.73)\end{array}$ & $\begin{array}{c}-119.43^{* * *} \\
(-4.23)\end{array}$ & $\begin{array}{c}-55.80 * * * \\
(-6.84)\end{array}$ & $\begin{array}{c}-18.83 * * \\
(-2.11)\end{array}$ \\
\hline Short estimation period & $\begin{array}{c}0.08 \\
(0.44)\end{array}$ & $\begin{array}{c}0.12 \\
(0.65)\end{array}$ & $\begin{array}{l}-0.85^{*} \\
(-1.73)\end{array}$ & $\begin{array}{l}0.60^{*} \\
(1.67)\end{array}$ & $\begin{array}{c}-0.64 * * * \\
(-2.98)\end{array}$ & $\begin{array}{c}0.03 \\
(1.62)\end{array}$ & $\begin{array}{c}0.15 \\
(1.26)\end{array}$ & $\begin{array}{c}-0.58 \\
(-1.49)\end{array}$ & $\begin{array}{c}-0.32 \\
(-1.19)\end{array}$ & $\begin{array}{l}1.00^{*} \\
(1.70)\end{array}$ \\
\hline $\begin{array}{l}\text { Analyst preference } \\
\times \text { Short estimation period }\end{array}$ & $\begin{array}{c}2.84 \\
(0.24)\end{array}$ & $\begin{array}{c}5.31 \\
(0.21)\end{array}$ & $\begin{array}{l}-28.01 \\
(-1.63)\end{array}$ & $\begin{array}{l}-32.49 \\
(-1.54)\end{array}$ & $\begin{array}{l}37.05 \\
(1.57)\end{array}$ & $\begin{array}{c}3.12 \\
(0.20)\end{array}$ & $\begin{array}{l}11.99 \\
(0.65)\end{array}$ & $\begin{array}{l}11.17 \\
(0.35)\end{array}$ & $\begin{array}{c}28.93 * * * \\
(3.07)\end{array}$ & $\begin{array}{c}-23.47^{* *} \\
(-2.32)\end{array}$ \\
\hline
\end{tabular}

Panel D: Analyst Preferences Separate From Broker Preferences

Changes in corporate policies in excess of changes in mean industry-year corporate policies

\begin{tabular}{|c|c|c|c|c|c|c|c|c|c|c|}
\hline & $\begin{array}{l}\text { CAPEX / } \\
\text { TA }\end{array}$ & $\begin{array}{c}\mathrm{R} \& \mathrm{D} / \\
\mathrm{TA}\end{array}$ & $\begin{array}{l}\mathrm{ACQN} / \\
\mathrm{TA}\end{array}$ & $\begin{array}{l}\Delta \mathrm{DEBT} / \\
\mathrm{TA}\end{array}$ & $\begin{array}{l}\text { EQUITY } \\
\text { ISS / TA }\end{array}$ & DIV / TA & $\begin{array}{l}\text { SHARE } \\
\text { REP / TA }\end{array}$ & $\begin{array}{l}\Delta \mathrm{CASH} / \\
\mathrm{TA}\end{array}$ & $\begin{array}{l}\text { DEBT / } \\
\text { TA }\end{array}$ & $\begin{array}{c}\text { CASH / } \\
\text { TA }\end{array}$ \\
\hline Analyst preference (A) & $\begin{array}{c}-27.63 * * * \\
(-5.34)\end{array}$ & $\begin{array}{c}-32.09 * * \\
(-2.16)\end{array}$ & $\begin{array}{c}-72.67 * * * \\
(-8.46)\end{array}$ & $\begin{array}{c}-66.71 * * * \\
(-5.93)\end{array}$ & $\begin{array}{c}-86.50 * * * \\
(-7.23)\end{array}$ & $\begin{array}{c}-42.09 * * * \\
(-5.19)\end{array}$ & $\begin{array}{c}-70.17 * * * \\
(-7.56)\end{array}$ & $\begin{array}{c}-107.77 * * * \\
(-7.31)\end{array}$ & $\begin{array}{c}-35.48 * * * \\
(-6.81)\end{array}$ & $\begin{array}{c}-35.65 * * * \\
(-6.30)\end{array}$ \\
\hline Broker preference (B) & $\begin{array}{c}32.00 * * * \\
(2.89)\end{array}$ & $\begin{array}{l}28.19 \\
(1.33)\end{array}$ & $\begin{array}{c}-6.99 \\
(-0.27)\end{array}$ & $\begin{array}{c}-6.40 \\
(-0.24)\end{array}$ & $\begin{array}{c}48.31 * \\
(1.91)\end{array}$ & $\begin{array}{c}23.81 * \\
(1.73)\end{array}$ & $\begin{array}{c}-4.25 \\
(-0.22)\end{array}$ & $\begin{array}{l}-39.22 \\
(-1.12)\end{array}$ & $\begin{array}{c}6.82 \\
(0.62)\end{array}$ & $\begin{array}{c}2.55 \\
(0.17)\end{array}$ \\
\hline $\begin{array}{l}\text { Economic magnitude of }(\mathrm{A}) \\
\text { Economic magnitude of }(\mathrm{B})\end{array}$ & $\begin{array}{c}-0.32 \% \\
0.17 \%\end{array}$ & $\begin{array}{c}-0.28 \% \\
0.08 \%\end{array}$ & $\begin{array}{l}-0.68 \% \\
-0.03 \%\end{array}$ & $\begin{array}{l}-0.49 \% \\
-0.02 \%\end{array}$ & $\begin{array}{c}-1.38 \% \\
0.31 \%\end{array}$ & $\begin{array}{c}-0.07 \% \\
0.02 \%\end{array}$ & $\begin{array}{l}-0.51 \% \\
-0.01 \%\end{array}$ & $\begin{array}{l}-1.42 \% \\
-0.16 \%\end{array}$ & $\begin{array}{c}-1.00 \% \\
0.08 \%\end{array}$ & $\begin{array}{c}-0.85 \% \\
0.02 \%\end{array}$ \\
\hline
\end{tabular}




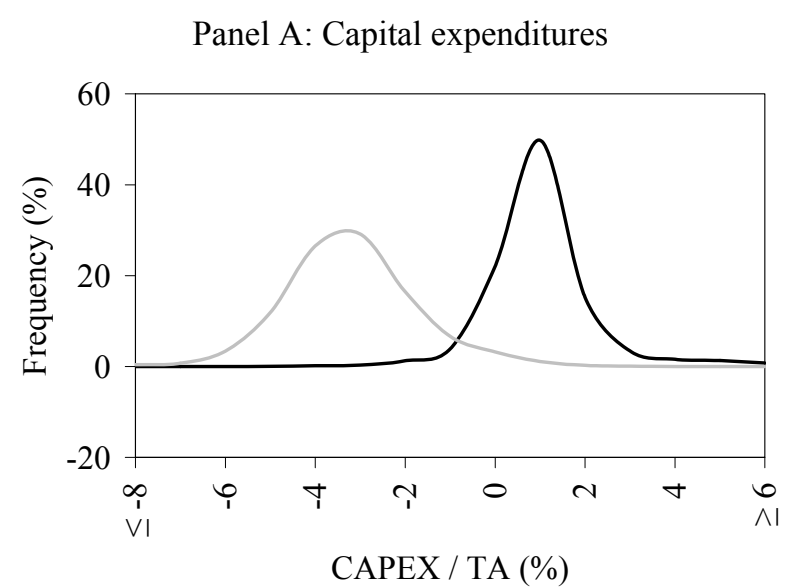

Panel C: Acquisitions expenditures

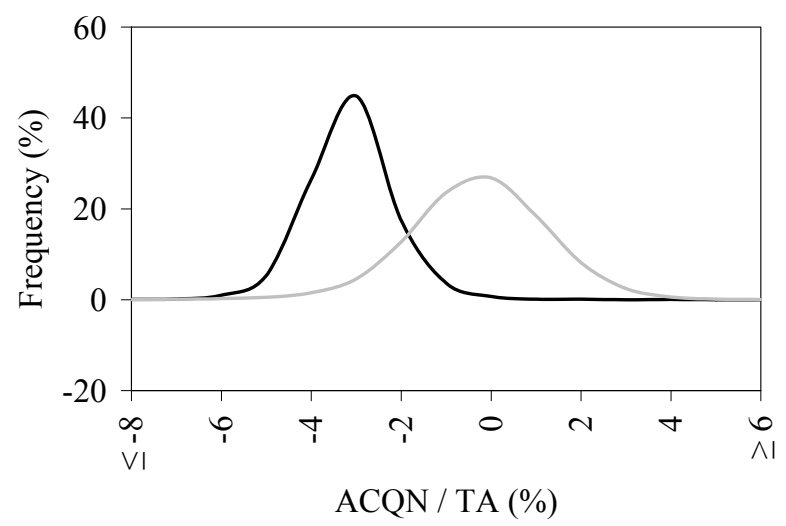

Panel E: Equity issuance

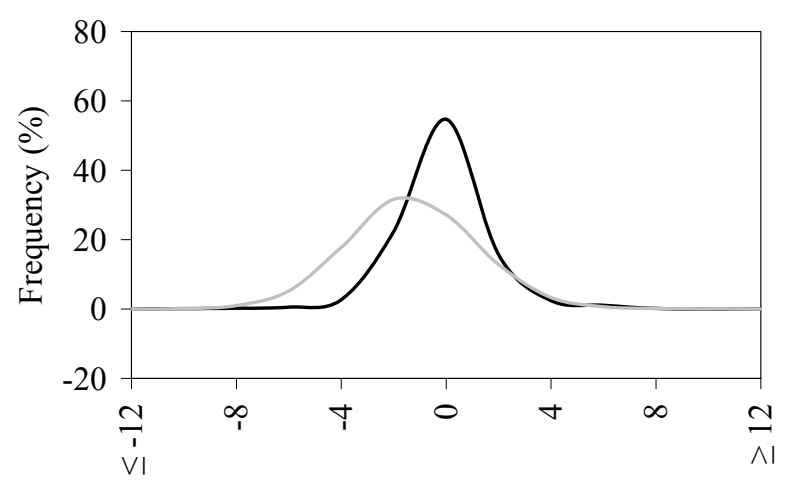

EQUITY ISS / TA (\%)
Panel B: Research and development expenditures

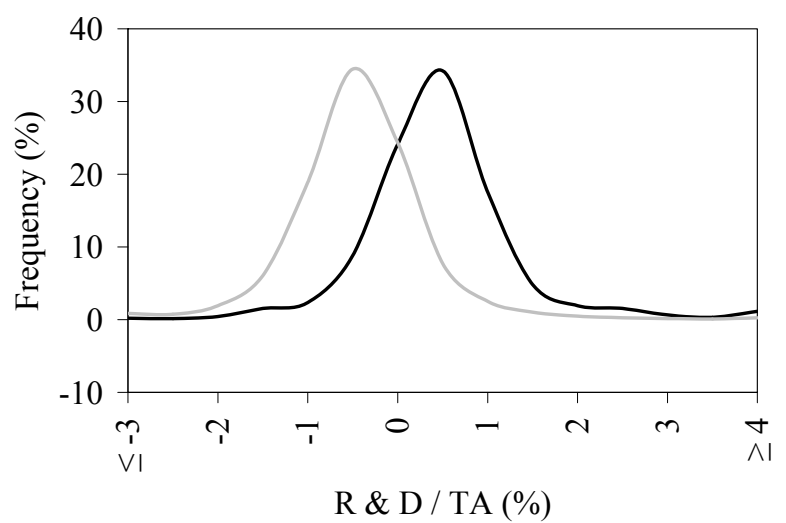

Panel D: Change in debt

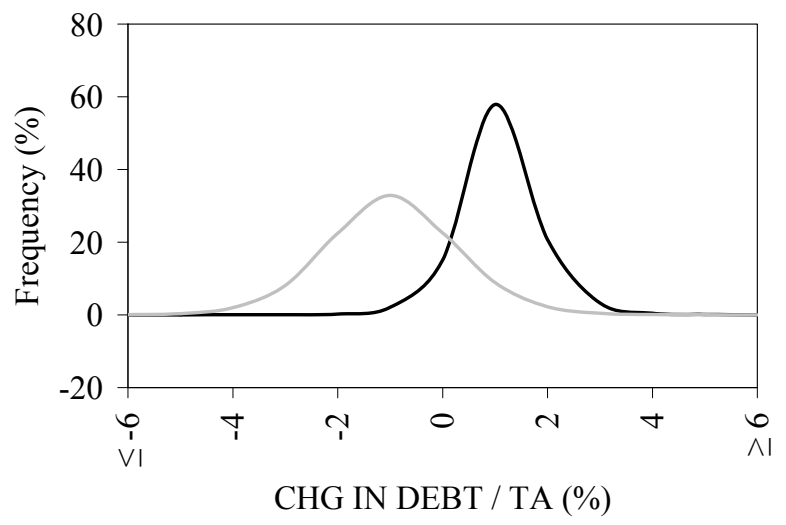

Panel F: Dividends

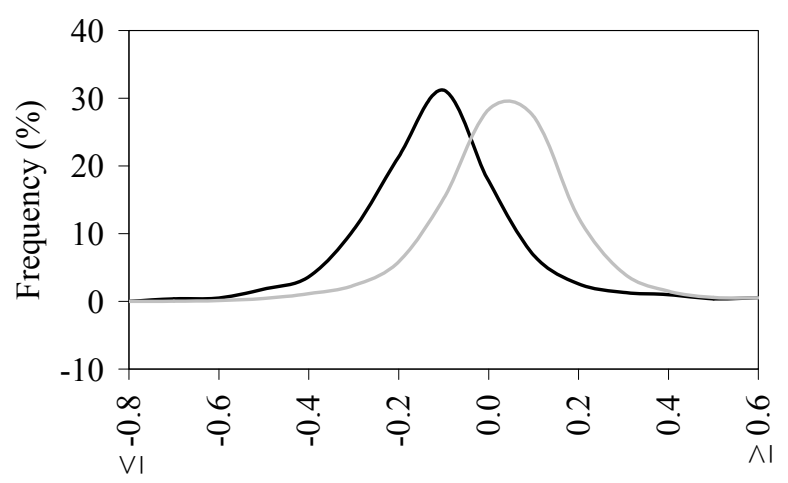

DIV / TA (\%) 
Panel G: Share repurchases

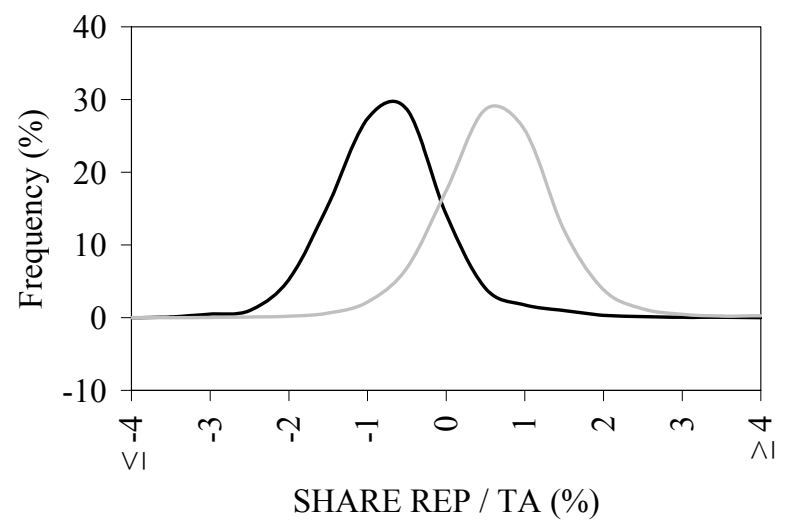

Panel I: Debt

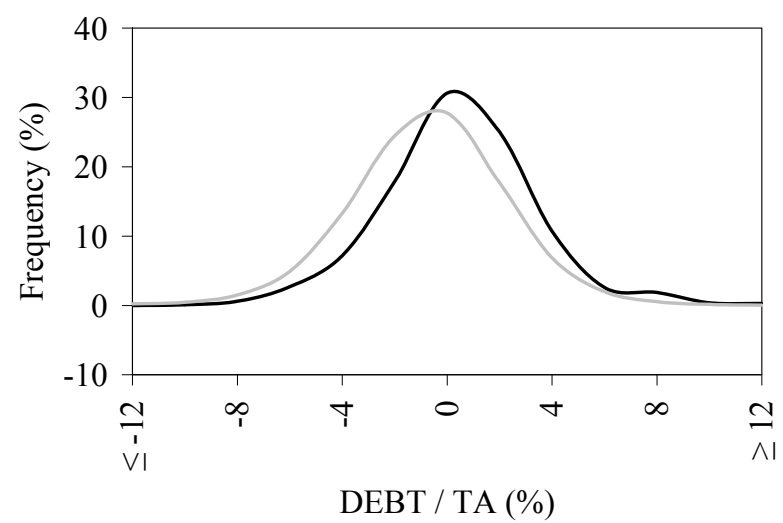

Panel H: Change in cash holdings

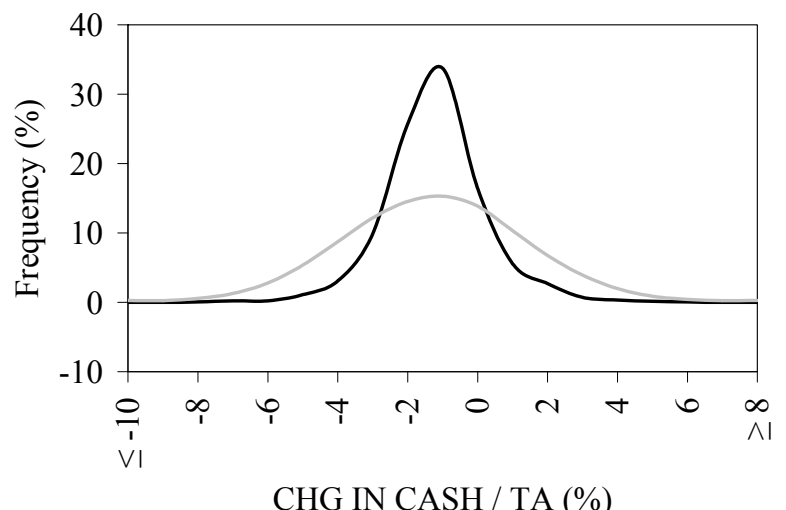

Panel J: Cash holdings

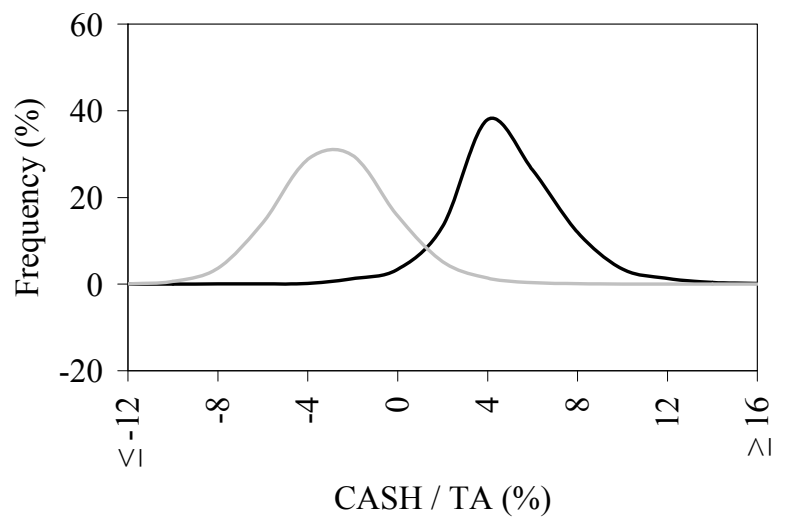

Figure 1. The distributions of true and simulated analyst preferences for corporate policies. This figure presents the true distribution of analyst preferences (dark line) for corporate policies as well as the distribution of simulated preferences (light line). The analysts in the sample are 1,811 analysts between 1984 and 2009. All variables are defined in Appendix Table 1. 
Panel A: The distribution in calendar time of analysts that disappear

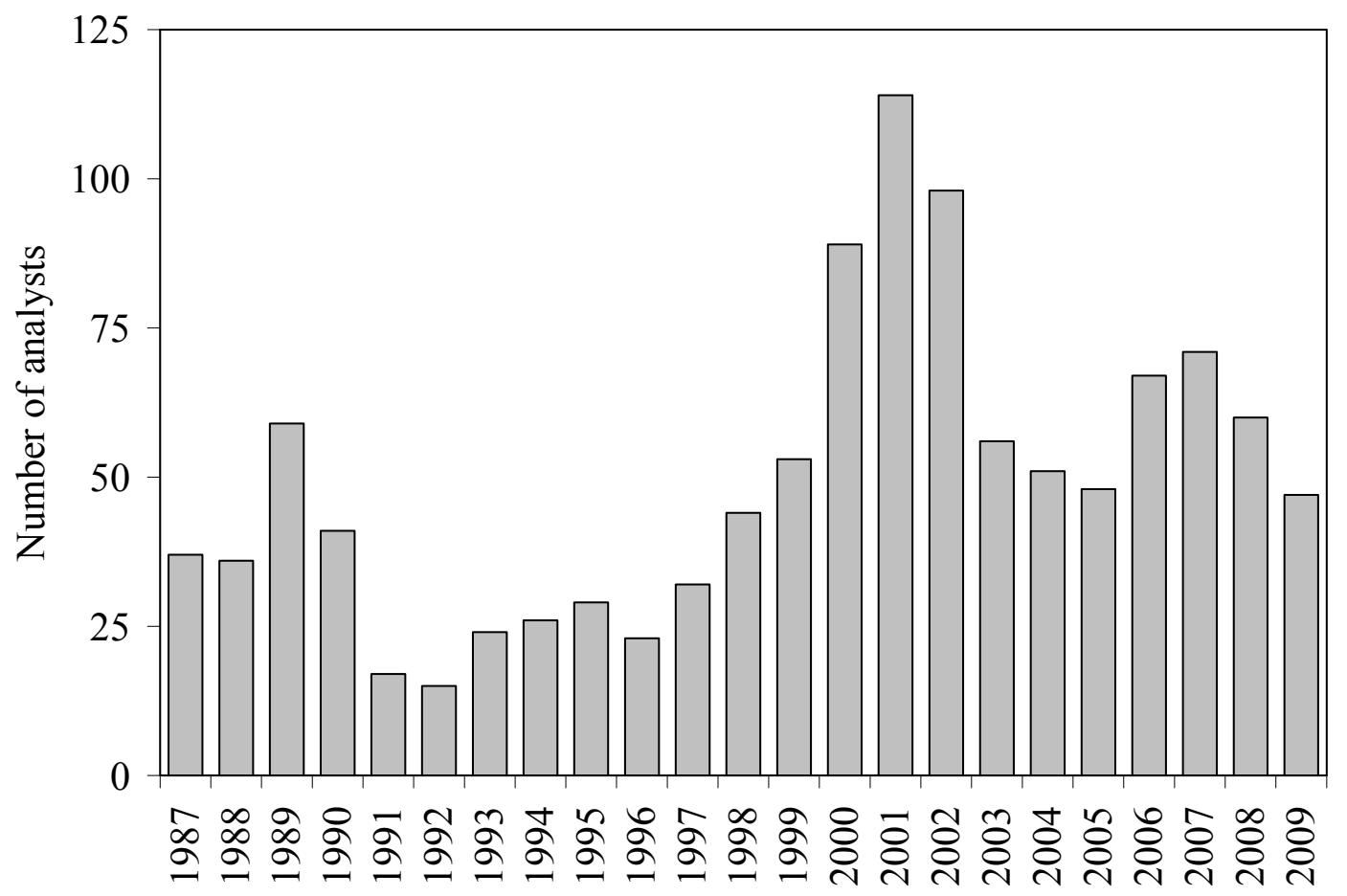

Panel B: The distribution in calendar time of firms that lose an analyst

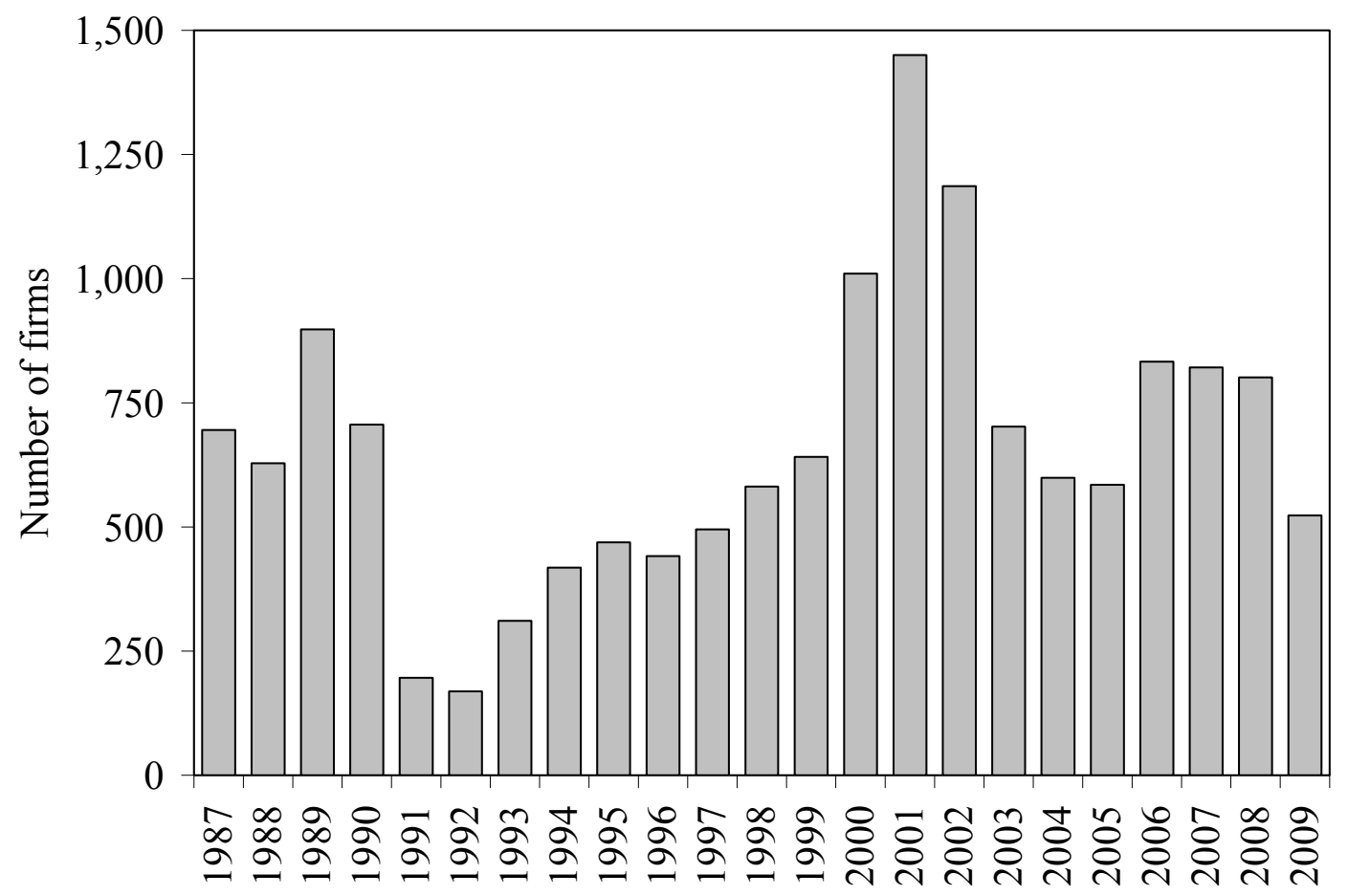

Figure 2. The distribution in calendar time of analysts that disappear and firms that lose an analyst. This figure presents the distribution of analysts and firms in the sample in calendar time. The sample comprises 15,158 analyst-year-firm observations corresponding to 1,137 unique analysts and 4,182 unique firms between 1987 and 2009. The analysts in the sample disappear and terminate coverage of all firms on their coverage list. The firms in the sample are publicly traded U.S. operating firms excluding financials and utilities. 
Panel A: Capital expenditures

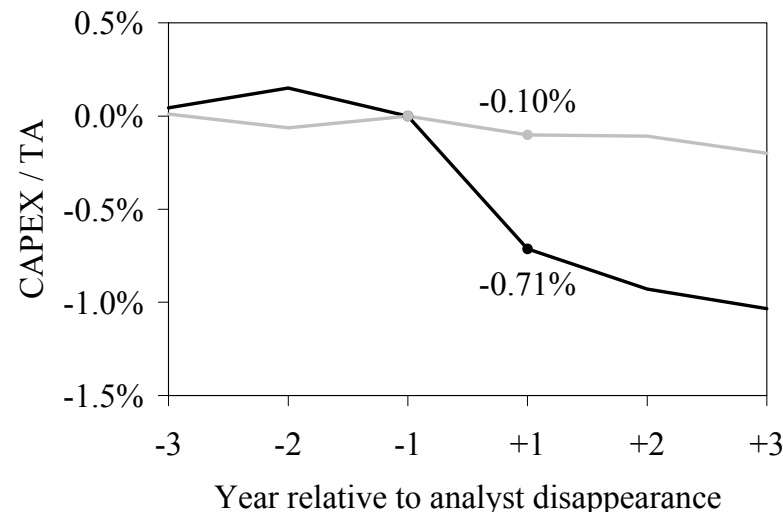

Panel C: Acquisitions expenditures

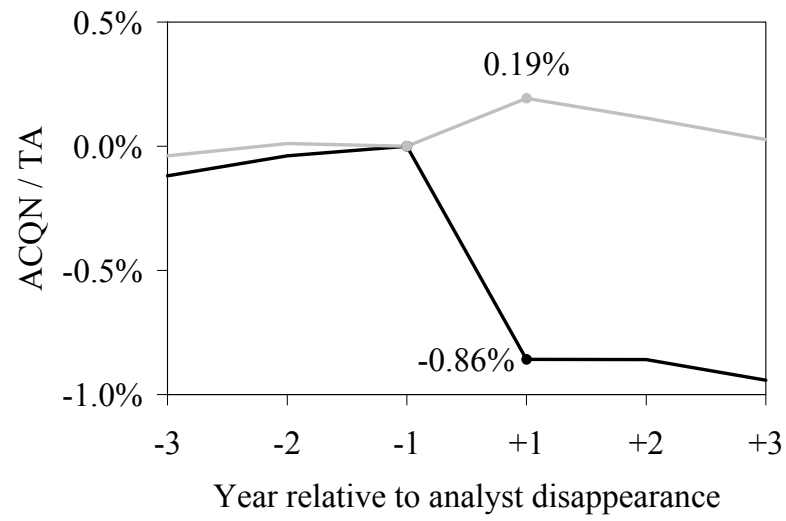

Panel E: Equity issuance

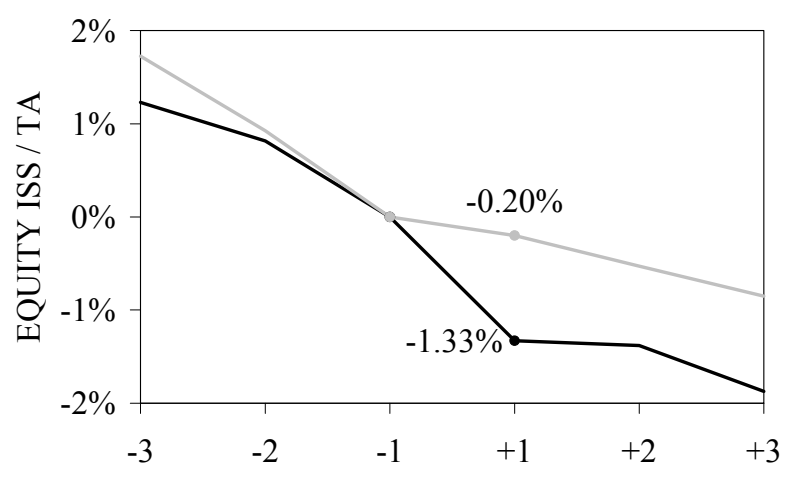

Year relative to analyst disappearance
Panel B: Research and development expenditures

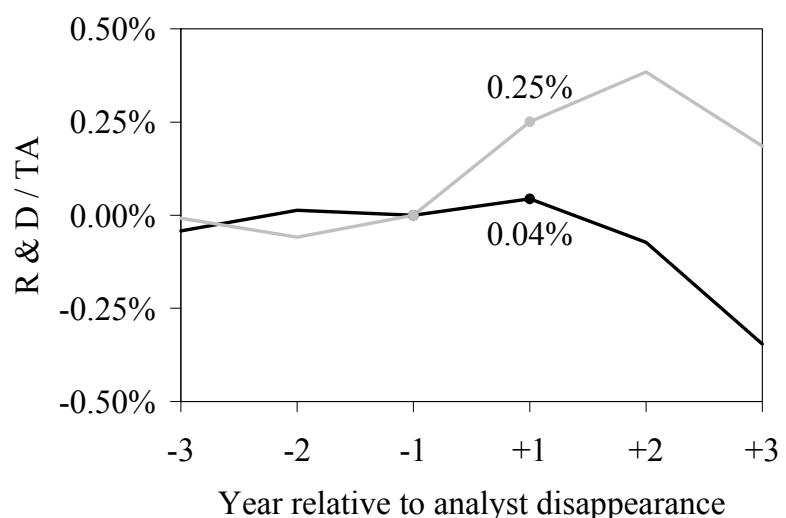

Panel D: Change in debt

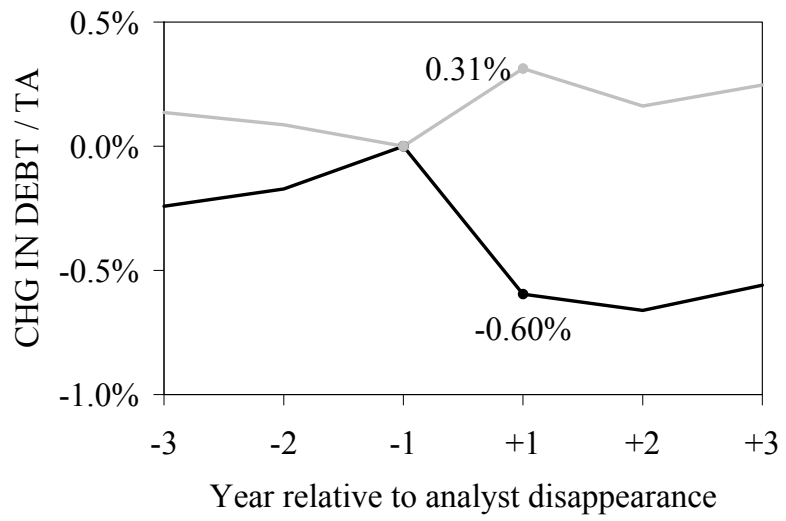

Panel F: Dividends

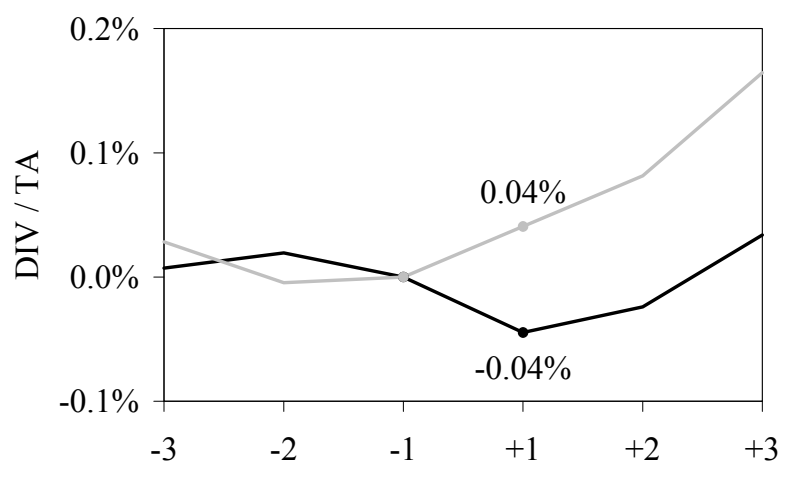

Year relative to analyst disappearance 
Panel G: Share repurchases

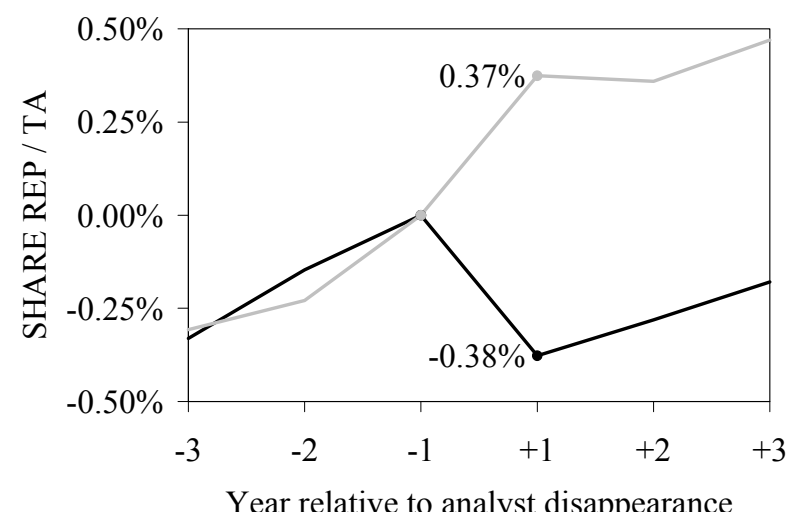

Panel I: Debt

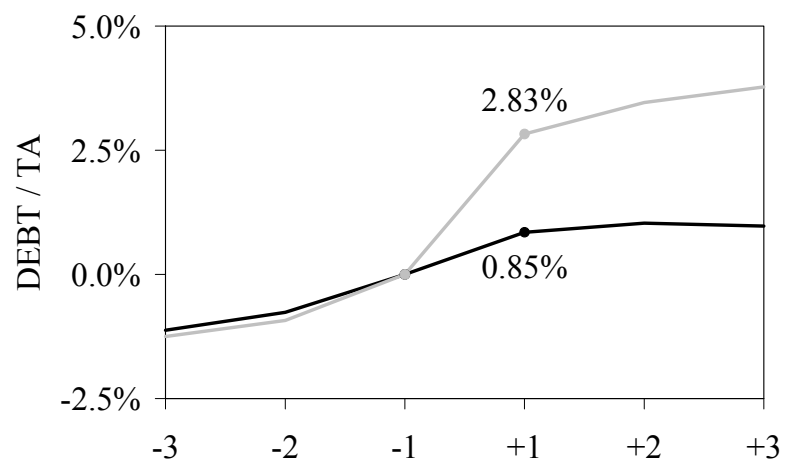

Year relative to analyst disappearance
Panel H: Change in cash holdings

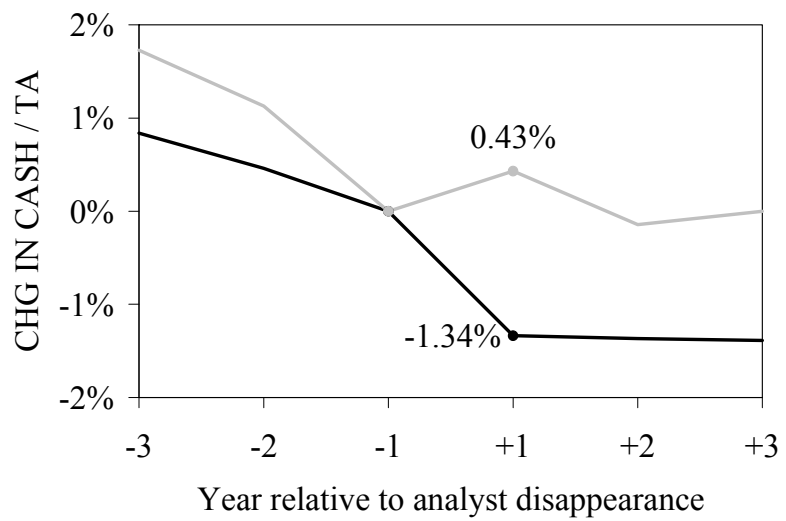

Panel J: Cash holdings

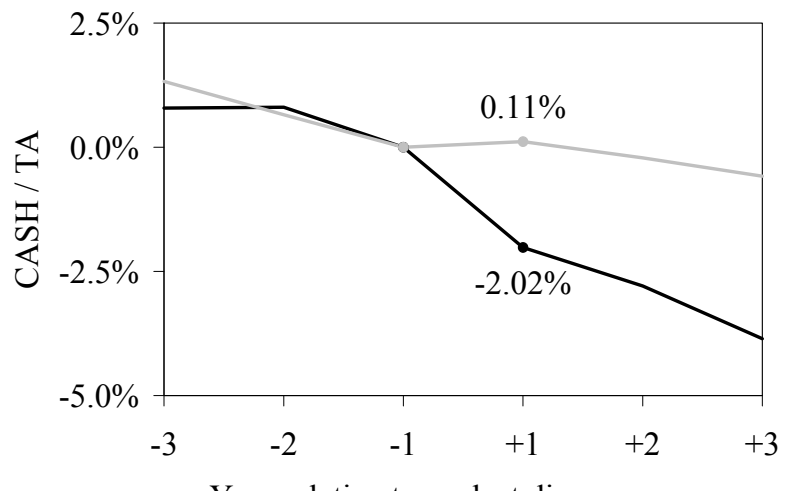

Figure 3. Corporate policies in event time for firms with positive analyst preferences and for firms with negative analyst preferences. This figure presents mean corporate policies in event time for firms with positive analyst preferences (dark line) and for firms with negative analyst preferences (light line). The sample comprises 15,158 analyst-year-firm observations corresponding to 1,137 unique analysts and 4,182 unique firms between 1987 and 2009. The analysts in the sample disappear and terminate coverage of all firms on their coverage list. The firms in the sample are publicly traded U.S. operating firms excluding financials and utilities. Separately for positive and negative analyst preferences, corporate policies are adjusted so that they equal zero at the year before the analyst disappears. For each corporate policy, analysts that disappear with preferences above the median are classified as analysts with positive preferences and analysts that disappear below the median are classified as analysts with negative preferences. Analyst preferences are measured at the year before the analyst disappears. All variables are defined in Appendix Table 1. 


\section{Appendix Table 1 \\ Variable Definitions}

This table presents variable definitions. Corporate policies are measured in excess of mean industry-year corporate policies except for analyst preferences. Industry is defined using two-digit SIC codes. * indicates that the variable is defined using Compustat data items.

\begin{tabular}{|c|c|}
\hline \multicolumn{2}{|c|}{ Panel A: Corporate Policy Variables, Control Variables, and Other Variables } \\
\hline Name & Definition \\
\hline $\begin{array}{l}\text { Corporate policy variables } \\
\text { - CAPEX / TA or capital expenditures } \\
\text { - R \& D / TA or research and development } \\
\text { expenditures } \\
\text { - ACQN / TA or acquisitions expenditures } \\
\text { - } \triangle \text { DEBT / TA or change in debt } \\
\text { - EQUITY ISS / TA or equity issuance } \\
\text { - DIV / TA or dividends } \\
\text { - SHARE REP / TA or share repurchases } \\
\text { - } \triangle \text { CASH / TA or change in cash holdings } \\
\text { - DEBT / TA or debt } \\
\text { - CASH / TA or cash holdings }\end{array}$ & $\begin{array}{c}\text { AQC/AT } * \\
(\mathrm{DLCCH}+\mathrm{DLTIS}-\mathrm{DLTR}) / \mathrm{AT} * \\
\text { SSTK/AT * } \\
\text { DV/AT * } \\
\text { PRSTKC/AT }^{*} \\
\text { CHECH/AT * } \\
(\mathrm{DLC}+\mathrm{DLTT}) / \mathrm{AT} * \\
\text { CHE/AT } *\end{array}$ \\
\hline $\begin{array}{l}\text { Control variables } \\
\text { - Size } \\
\text { - Market-to-book } \\
\text { - Cash flow-to-total assets } \\
\text { - Stock returns } \\
\text { - Volatility }\end{array}$ & 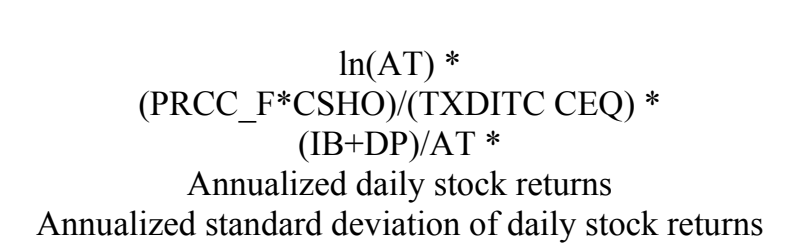 \\
\hline $\begin{array}{l}\text { Other variables } \\
\text { - Analyst coverage } \\
\text { - Market capitalization } \\
\text { - Firm age }\end{array}$ & $\begin{array}{c}\text { Number of analysts covering a firm } \\
\text { PRCC_F*CSHO * } \\
\text { Number of years the firm has been publicly traded }\end{array}$ \\
\hline \multicolumn{2}{|c|}{$\begin{array}{l}\text { - Analyst preferences: The sample is the same panel of analysts, years, and firms as above. The corporate policy } \\
\text { is regressed on analyst fixed effects, year fixed effects, firm fixed effects, and lagged control variables. Analyst } \\
\text { fixed effects are dummy variables that equal one for a given analyst, for a given year, and for a given firm if that } \\
\text { analyst that year covers that firm, and they equal zero otherwise. The control variables are size, market-to-book, } \\
\text { cash flow-to-total assets, stock returns, and volatility. The resulting coefficient estimates on the analyst fixed } \\
\text { effects are the fixed effects analyst preference for that corporate policy. }\end{array}$} \\
\hline \multicolumn{2}{|c|}{$\begin{array}{l}\text { - Simulated analyst preferences: For every analyst, for every year, and for every industry covered by the analyst, } \\
\text { firms are randomly assigned to the analyst such that the number of randomly assigned firms in the industry equals } \\
\text { the number of true firms covered by the analyst in the industry. Firms covered by more analysts have a } \\
\text { proportionately higher probability of being selected. After each random assignment, analyst preferences are } \\
\text { computed. Simulated analyst preferences are generated through } 1,000 \text { iterations of this procedure. }\end{array}$} \\
\hline $\mathrm{y}$ broker, $\mathrm{t}$ & erenc \\
\hline
\end{tabular}

